R E V I E W

D R A F T

\title{
MARKET ANALYSIS OF \\ GEOTHERMAL ENERGY FOR \\ CALIFORNIA AND HAWAII
}

October 1978

Prepared for:

U.S. DEPARTMENT OF ENERGY

Under Contract

ET-78-C-03-1529

Prepared by:

Science Applications, Inc.

1200 Prospect Street

La Jolla, California 92038 


\section{DISCLAIMER}

This report was prepared as an account of work sponsored by an agency of the United States Government. Neither the United States Government nor any agency Thereof, nor any of their employees, makes any warranty, express or implied, or assumes any legal liability or responsibility for the accuracy, completeness, or usefulness of any information, apparatus, product, or process disclosed, or represents that its use would not infringe privately owned rights. Reference herein to any specific commercial product, process, or service by trade name, trademark, manufacturer, or otherwise does not necessarily constitute or imply its endorsement, recommendation, or favoring by the United States Government or any agency thereof. The views and opinions of authors expressed herein do not necessarily state or reflect those of the United States Government or any agency thereof. 


\section{DISCLAIMER}

Portions of this document may be illegible in electronic image products. Images are produced from the best available original document. 


\section{SUMMARY}

The market for electric power production in California is adequate to absorb geothermal resources as they are currently profected to come on-line to the vear 2000 .

- An acceleration of geothermal development could motivate utilities to displace planned fossil fueled and nuclear plants with geothermal power plants.

- The recent provision for federal tax incentives can have a dramatic impact upon increasing the return on investment, reducing the price of fuel, or overcoming the capital cost limitations of developing a geothermal resource. This should provide an acceleration of development activities.

- The market for geothermal electric power production in Hawail is dependent upon an influx of new industry into the Islands, or shortages of petroleum products.

- The heavy reliance upon imported petroleum products in both states, makes native energy resources preferable wherever they can be supplied, because of balance of payment issues.

- The heaviest markets for direct heat industrial application are in the San Francisco Bay area, Los Angeles and other coastal counties in California. The Island of Oahu provides the major market in Hawaii.

In the case of Hawail and Callfornia the proven resources for direct heat industrial use do not coincide with the urban market locations. 
- Economical processing of agricultural products may require scheduling of crop harvest times to assure adequate process plant utilization.

- Projected scenarios for power-on-line at the Heber site in Imperial County have accelerated by $1-2$ years in the past year, indicating increased demand for geothermal energy.

- Energy conservation plans are in effect for many industries, indicating the concern over rising energy costs and energy avallability, making geothermal more attractive.

- Geothermal energy is a heterogeneous product, which can be cost competitive, marginally competitive, or cost prohibitive, depending upon site, application, and market. Individual market analysis for particular applications w11l be necessary for product-specific ventures.

Recommendations include:

- Demonstration of liquid-dominated geothermal electric power generation.

- Enactment of tax incentives.

- Demonstration of industrial uses including

- Food Processing

- Lumber \& Paper

- Chemical

- Market analysis of Lumber \& paper industries in Northern California.

- Overview of the Chemical industrles in California and Hawaii. 
- Overview of the Food Processing industry in California.

- Assessment of industrial attitudes toward geothermal energy.

- Exploration of resources in proximity to major markets. 
1. INTRODUCTION

2. ENERGY PROFILES

2.1 California .................. 3

2.2 Hawail . . . . . . . . . . . . 6

3. MARKET FOR ELECTRIC POWER PRODUCTION . . . . . . . . . 9

3.1 California .................... 9

3.2 Hawaii ....................18

4. DIRECT USE OVERVIEW OF CALIFORNIA (SUMMARY) . . . . . . .21

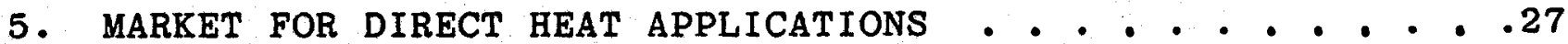

5.1 California . . . . . . . . . . . . . 27

5.1.1 Space Conditioning . . . . . . . . . . . .27

5.1 .2 Agribusiness . . . . . . . . . . . . . .28

5.1 .3 Industrial Uses. . . . . . . . . . . . .32

5.2 Hawail. . . . . . . . . . . . . 39

6. MARKET PROSPECTS FOR MAJOR INDUSTRIAL DIRECT

USE CANDIDATES (The Nation's Market) . . . . . . . . . . .43

6.1 Food \& Kindred Products . . . . . . . . . . . .43

6.2 Lumber, Pulp \& Paper. . . . . . . . . . . . .45

6.3 Chemicals \& Allied Products . . . . . . . . . . .46

6.4 Rubber \& Miscellaneous Products . . . . . . . . . . . .49

6.5 Petroleum Refining . . . . . . . . . . . . 49

7. ALTERNATIVE ENERGY cOSTS . . . . . . . . . . . . . . . . . .

8. CAPITAL COSTS OF SUPPLYING COMPETITIVE GEOTHERMAL FUEL • • .57

9. THE IMPACT OF TAX INCENTIVES . . . . . . . . . . . . 60

9.1 Depletion Allowance . . . . . . . . . . . 60

9.2 Intangible Drilling Costs.............. . . . . .

9.3 Investment Tax Credit ...............61

10. RECOMMENDATIONS _. . . . . . . . . . . . . . 67

BIBLIOGRAPHY ...................... . . . . .

APPENDIX A - Purchased Fuels and Electric Energy

Consumed in California Counties for Six Major

Process Heat Using Industries. 


\section{LIST OF TABLES}

No.

TITLE

PAGE

1 Quantity and cost of Purchased Fuel and Electricity for Heat and Power for Selected Industries in California . . . . . . . . . . 3 California Energy Use Projections ......... 7 Commission Adopted Peak Demand Forecasts . . . . . 9 Commission Adopted Sales Forecasts . . . . . . . 10 Utility Electric Power Forecasts $\mathrm{MW}_{\mathrm{e}} \ldots \ldots \ldots \ldots$

6 Current California Utility Geothermal Additions Forecast . . . . . . . . . . . . . 13

7 Comparison of Busbar Costs of Electric Power Using the "GEYSER" Model . . . . . . . . . . 16

Typical Electric Bills (Residential) for Hawaii . . 19

9 National Ranking, Share of Production, and Harvested Acreage for California's Commodities . . . . 30

Harvest Seasons for California Crops ... . . . . 31

11 Market Indicators Top 12 Counties (Billion BTUs) in California ........... . . . . 37

12 Energy Purchased by Six Major Process Heat-Using Industries for the State of Hawaii . . . . . . 40

13 Hawaii State Fixed Industries Process Heat Energy Consumption . . . . . . . . . . . . . 41

14 Food and Kindred Products: Trends and Projections 1975-78

15 Wood Pulp Production: Actual 1968-76; Projections 1977-78 . . . . . . . . . 46

Energy Consumption of the Chemical Industry

17 Energy Consumption by the Chemical Industry Utilization by Conversion Process . . . . . . 48

18 Chemicals and Allied Products: Projections 1976-78. 
LIST OF TABLES (CONT)

No.

TITLE

PAGE

19 Rubber and Plastics: Trends and Projections

1975-78 . . . . . . . . . . . 49

20

California Refineries........... 51

21 Fuel Costs for Major Utilities in Callfornia

and Hawail 1971-1976 .. . . . . . . . . 53

22 Estimated Landed Cost of Imported Crude Petro-

leum From Selected Countries . . . . . . . . 54

23 Cost Per Million BTU for Pacific Region of U.S. 55

24 Range of Electricity Costs for Selected Cities

in California and Hawaii for Lighting, Refrig-

eration, Cooking, and Water Heating..... 56

25 Basic Assumptions for Costing Direct Heat

Applications of Geothermal Energy ..... . . . 58

26 Capital Cost Limitation for Rates of Return

on Investment to Provide $20 \times 10^{9} \mathrm{BTU} / \mathrm{Yr}$. . . . 63

27 Impact of Tax Incentives Upon Capital Cost

Limitations of System to Produce $20 \times 10^{9}$ BTU's

Per Year .................. 64

28 Impact of Tax Incentives for a Large Company . . 65

29 Impact of Tax Incentives Upon a Smaller Company

With A Tax Liability Limitation . . . . . . 66 


\section{LIST OF FIGURES}

NO.

TITLE

PAGE

1

California's Energy Supply/Demand _ . . . . . 4

2

State of Hawail Energy Supply/Demand _ . . . . 8

3

Projection of Geothermal Electric Power

Generation in California . . . . . . . . .

4

Comparison of Updated Scenario for Imperial

County, SAI (1978) with MITRE (1977), Installed

Capacity, Geothermal $\mathrm{MW}_{\mathrm{e}}$ On Line . . . . . . 17

5

Resource Zones from the Direct Use Overview .

6

BTU's in Production Resulting from Capital

Investment . . . . . . . . . . . . 26

7 Total Energy Purchased for Selected Industries, 1976 (Billion BTU's) . . . . . . . . .

Energy Use Per Square Mile for Selected Industries, 1976 (Billion BTU/SQ. MI.) . . . .

Energy Use Per Capita for Selected Industries, 1976 (Million BTU Per Capita). . . . . . .

Projection of Geothermal MBtu/HR in Operation for Direct Heat Applications in California...

11 Projection of Geothermal MBtu/Hr. in Operation for Direct Heat Applications in Hawaii . . . . 


\section{MARKET ANALYSIS OF GEOTHERMAL ENERGY FOR \\ CALIFORNIA AND HAWAII}

\section{INTRODUCTION}

The purpose of this paper is to investigate the market for geothermal energy in California and Hawaii for both electric power production and direct use applications. [Geothermal energy is a heterogeneous product with a wide variety of applications. The approach of this study is generic, although some particular industries are singled out because they are major energy users. ofening.

Electric power generation is an important geothermal use and is being given considerable attention by the Department of Energy, the State Energy Commission, the Public Otility Commission and the public and private utilities. Electric power production is addressed within this paper; however, greater focus is placed upon direct heat applications, particulariy industrial uses, which could stand to gain substantial benefits from development of geothermal resources. A market analysis of direct heat applications is a complex undertaking because there are so many possible applications and products. Such an analysis is usually performed for a specific product within a specified market. This document is an overview, prepared to help local, state, and federal decision makers, as well as to aid entrepreneurs to help in the preparation of site-specific market analyses. It is hoped that the document will be used as $a$ working tool by those interested in developing the geothermal alternative energy use. The presentation provides more information than analysis.

California and Hawail are both heavily dependent upon petroleum products for energy supply. The increasing costs of domestic and imported crude oil can have a substantial impact upon the cost of many products, including electric power, processed foods, I umber, paper, and chemicals. There now exists 
an opportunity for entrepreneurial talent to take advantage of untapped resources which may provide a considerable competitive advantage for the present and the future.

Information reported in this paper includes an energy profile of each state, a discussion of the markets for electric power generation and direct heat applications, market indicators for mafor industrial uses, the results of a direct use overview prepared by SAI, a projection of local and national markets, $a$ presentation of competitive energy costs, a discussion of capital cost limitations involved with producing competitive power, and the impact of tax incentives in making geothermal energy cost competitive. 


\section{CURRENT \\ 2. $\wedge$ ENERGY PROF ILES}

2.1

CALIFORNIA

$$
6 \% \text { ? }
$$

California's energy supply is heavily dependent upon petroleum (69\%) and natural gas (25\%). The components of energy supply and demand are given 1n Figure 1. California consumes the largest amount of energy of the states in the Pacific Region. From 1970 to 1976, California's installed capacity for electric power generation increased at an average of $3.6 \%$ per year. In 1976, installed capacity was 35,300 MWe. Of California's electric power production, $33.0 \%$ goes to residential use, $32.4 \%$ to commercial activity, and $31.0 \%$ to industrial uses. Natural gas consumption in California in 1976 was 1.618 quads: $37 \%$ went to residential use, $13.2 \%$ to commercial, and $49.56 \%$ to industrial use. Manufacturing industries in California purchased .624 quads of fuel and electric energy for heat and power purposes in 1976. Table 1 below displays the energy purchased by major process heat users in the state and the cost of that energy,

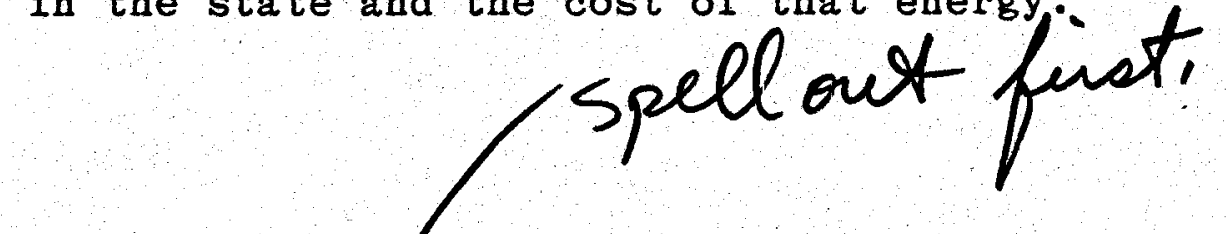

Table 1. Quantjty and cost of Purchased Fuel and Electricity for Heat and Power for Selected Indystries in California - 1976

\begin{tabular}{|c|c|c|c|}
\hline & & $\begin{array}{c}\text { Trillion } \\
\text { BTU } \\
\end{array}$ & $\begin{array}{l}\text { Millions } \\
\text { Of Dollars }\end{array}$ \\
\hline Food \& Kindred P & ducts & 98.5 & 223.2 \\
\hline Lumber \& Wood & cts & 19.6 & 61.1 \\
\hline Paper \& Allied & ducts & 36.7 & 88.4 \\
\hline Chemicals \& Al & Products & 60.9 & 147.8 \\
\hline Petroleum \& Coal & oducts & 134.9 & 277.5 \\
\hline
\end{tabular}
The OBERS projections for earnings growth in California range from 3.7 to $4.2 \%$ per year. Population growth in California averages $1.2 \%$ per year. 

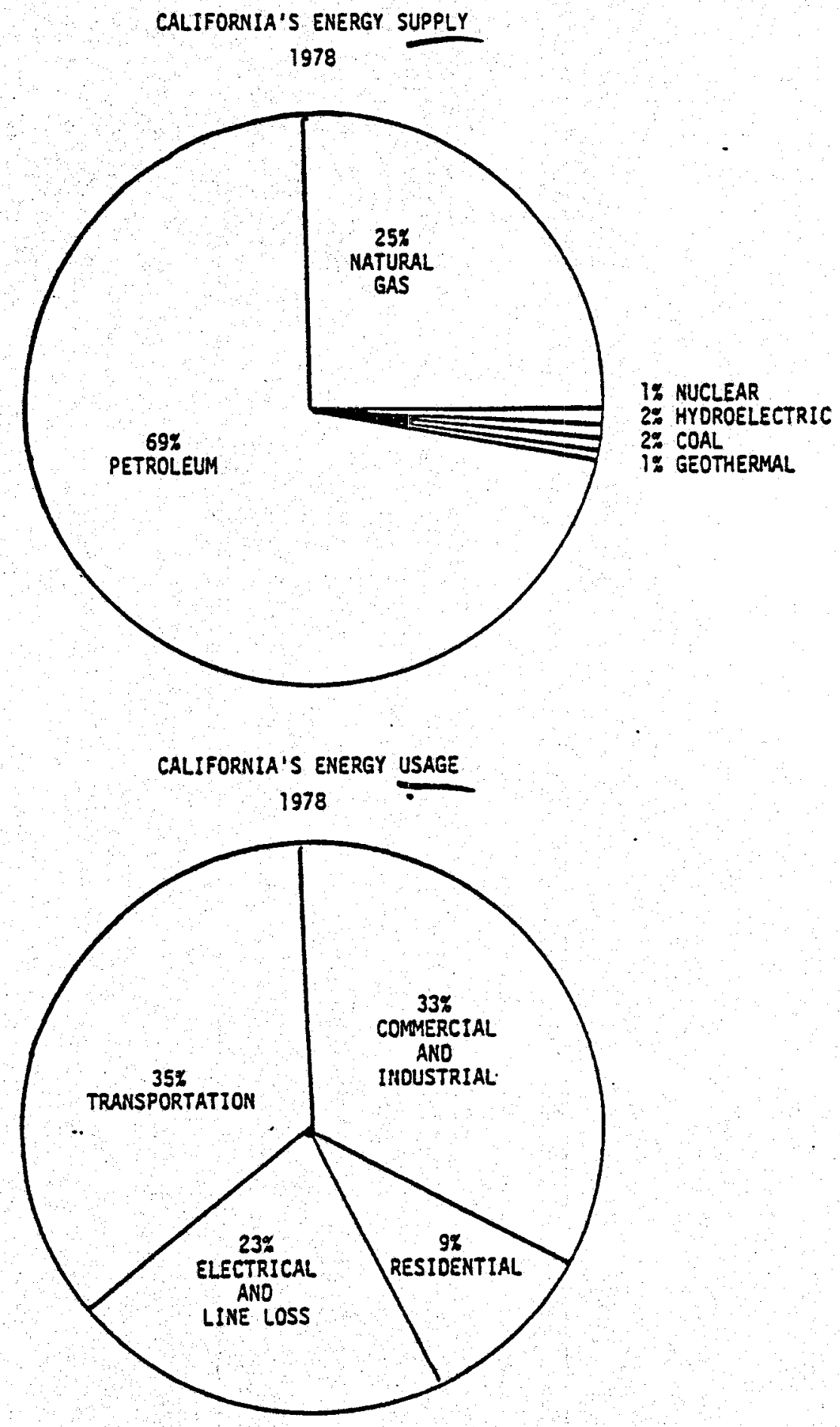

Figure 1. California's Energy Supply/Demand 
Although California produces a large amount of crude o11, it has been importing large amounts of foreign crude. In the past year, Alaskan North slope crude oil has lowered foreign crude oll's share of the California refiners' market from $49 \%$ in August 1977 to only $22 \%$ in August 1978. The foreign share of the market dropped from 29.4 million barrels to only 12.4 milition barrels for the month of August. It is also planned that geothermal energy can reduce the dependence upon foreign oil still further. The State of California has optimistic estimates of potential power on-line, projecting geothermal to be $12 \%$ of California's installed capacity by $1985,19.9 \%$ by 1995 , and $15.1 \%$ by the year 2000. Bringing about such an aggressive development schedule would require sufficient federal assistance to achieve parity with alternative fuels. Issues such as tax incentives are particularly important in California where geothermal energy is vigorously competing with oil, gas, nuclear, and coal for a position in the utilities energy mix. 0 the two states, California stands to gain the most from development of its geothermal resources. Table 2 displays energy use projections for California to the year 2000 from the State Energy Commission.

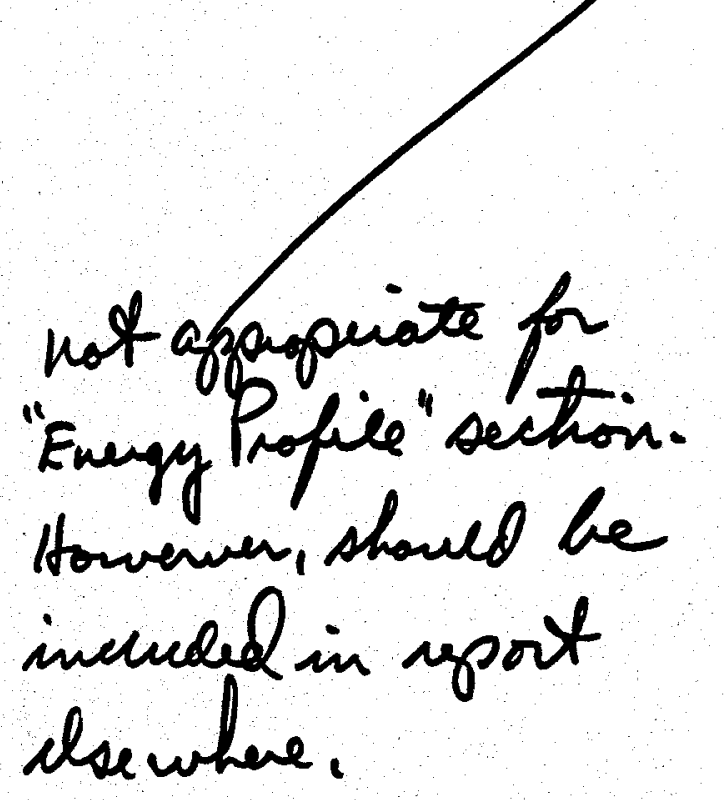


Table 2. California Energy Use Projections (In Trillion BTU)

\begin{tabular}{|c|c|c|c|c|c|c|c|}
\hline \multirow[b]{2}{*}{ Case } & \multicolumn{7}{|c|}{$\therefore \quad$ Year } \\
\hline & 1975 & 1980 & 1985 & 1990 & 1995 & 2000 & Sace/Growth \\
\hline \multicolumn{8}{|l|}{ Med1um } \\
\hline Residential & 720 & 789 & 858 & 959 & 1054 & 1152 & 1.9 \\
\hline Comperctal & 420 & 490 & 605 & 748 & 935 & 1169 & 4.2 \\
\hline Industrtal & 1505 & 1506 & 1546 & 1650 & 1776 & 1955 & 1.1 \\
\hline Iransporcation & 2095 & 2276 & 2363 & 2479 & 2730 & 2817 & 1.2 \\
\hline Tocal & 4740 & 5061 & 5372 & 5836 & 6495 & 7093 & 1.6 \\
\hline \multicolumn{8}{|l|}{ Low } \\
\hline Res1dent121 & 720 & 721 & 740 & 769 & 764 & 755 & 0.2 \\
\hline Comerctal & 420 & 442 & $\$ 11$ & 601 & 701 & 827 & 2.8 \\
\hline Indus er 1al & 1505 & 1506 & 2546 & 1650 & 1776 & 1955 & 1.1 \\
\hline Iransportation & 2095 & 1804 & 1717 & 1653 & 2775 & 1886 & -0.3 \\
\hline Total & 4740 & 4473 & 4514 & 4673 & 5016 & 5423 & 0.6 \\
\hline \multicolumn{8}{|l|}{ H1gh } \\
\hline Residential & 720 & 859 & 950 & 1065 & 1158 & 1261 & 2.1 \\
\hline Commercfal & 420 & 552 & 110 & 923 & 1196 & 1537 & 5.3 \\
\hline Industrial & 1505 & 2621 & 1885 & 2256 & 2675 & 3173 & 3.0 \\
\hline Transportacton & 2095 & 2415 & 2788 & 3172 & 3672 & 4126 & 2.7 \\
\hline Total & 4740 & 5447 & 6333 & 7414 & 8701 & 10122 & 3.0 \\
\hline
\end{tabular}


The energy supply in Hawail is highly dependent upon petroleum products, all of which are imported. Bagasse, the waste product from sugar refining, is burned to generate electric power in the refineries. This fuel supplies $7.8 \%$ of the energy in Hawail. A very small amount of hydroelectric power supplies $.2 \%$ of the energy in the Islands.

Over half of the energy consumed in Hawaii is used for transportation (54.9\%). Of this amount, $27.5 \%$ is consumed for air transportation, $15.6 \%$ for ground transportation, $3.5 \%$ for water transportation and $8.4 \%$ for military uses. The breakdown of energy supply and energy usage are given in Figure 2.

At the present time (1978) Hawailan petroleum is consumed at a rate of 112,000 bbl/day or about $225 \times 10^{12} \mathrm{BTU} /-$ year. By 1985, it is projected that Hawaii's needs will be $140,000 \mathrm{bbl} / \mathrm{day}, 225 \%$ increase in seven years. At this rate Hawali will need an increment of $8.0 \times 10^{12}$ BTU per year for each of the next seven years, in order to meet energy requirements.

From 1970 to 1976, Hawail's installed capacity for Electric power generation has increased at a rate of $4.3 \%$ per year. Installed capacity in 1976 was 1,400 MWe. Of Hawaii's electric power generation, $31.5 \%$ went to residential use, $20.4 \%$ to commercial use and $46.2 \%$ to industrial usage. There is very little natural gas consumption in Hawali (only .004 quad was consumed in 1976) as it must be manufactured from fuel oil. Hawaii's manufacturing industries purchased .0096 quad in 1976, the main industries being sugar refining and pineapple processing. Sugar refining accounted for $44 \%$ of the fuel and electric energy used by the manufacturing sector, purchasing 4.2 trillion BTU's at a cost of $\$ 10$ million. Geothermal energy can contribute to both electrical and direct heat capabilities in Hawaii. 
HAWAII'S ENERGY SUPPLY

1978

.2\% HYOROELECTRIC

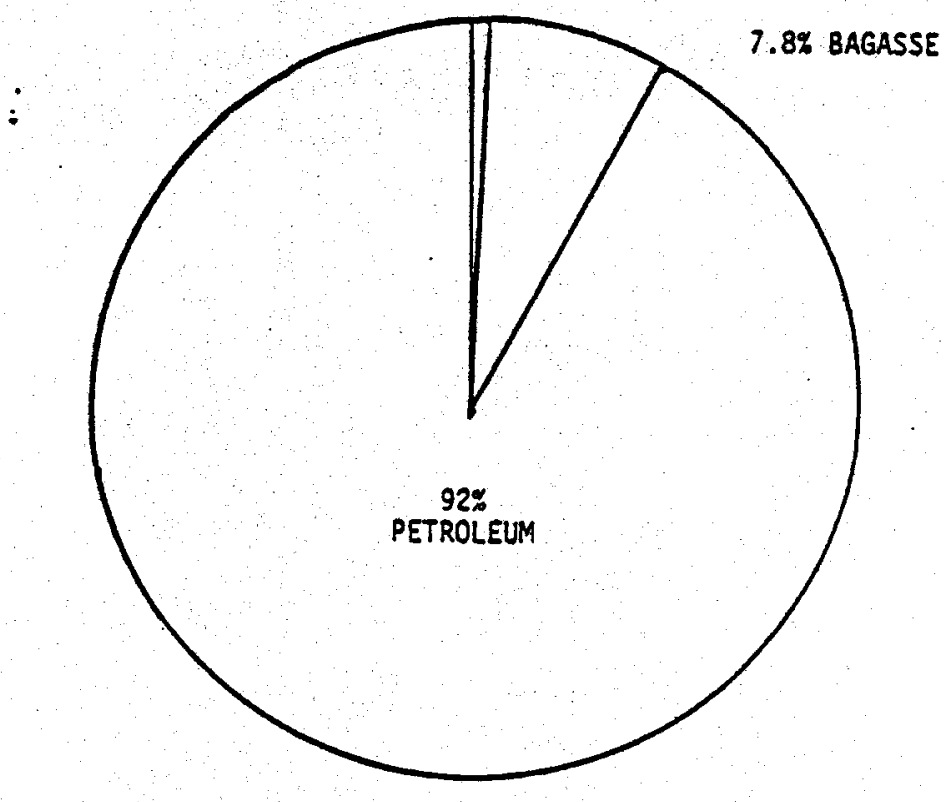

HAWAII'S ENERGY USAGE

1978

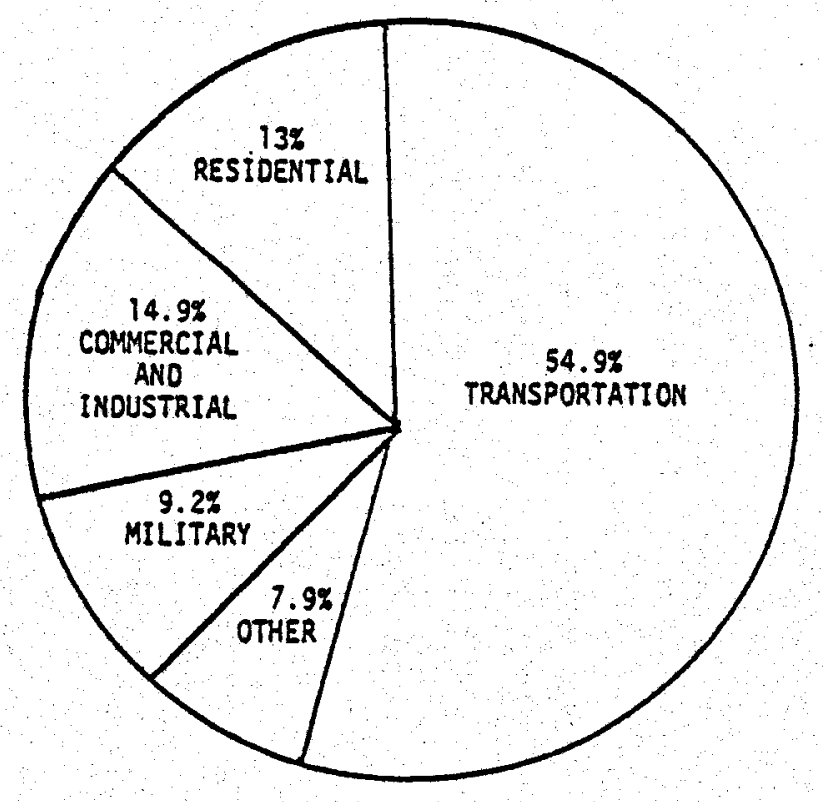

Figure 2. State of Hawaii Energy Supply/Demand 


\subsection{CALIFORNIA}

The California State Energy Commission has adopted electric utility sales forecasts and peak demand forecasts to the year 1995. Table 3 below displays the Commission's peak demand forecasts. The average growth rate from 1975 to 1985 is $4.1 \%$. In order to accommodate this growth, the average yearly increase In capacity for the 10 year period is 1,440 MWe. For the years 1985 to 1995, the average increase in peak capacity will be 1,740 MWe per year.

Table 3. Commission Adopted Peak Demand Forecasts (Megawatts)

\begin{tabular}{|c|c|c|c|c|c|c|}
\hline $\begin{array}{l}\text { Utility } \\
\text { Service } \\
\text { Area }\end{array}$ & 1975 & 1980 & 1985 & $\begin{array}{c}\text { Growth } \\
\text { Rate } \\
(75-85)\end{array}$ & 1995 & $\begin{array}{l}\text { Growth } \\
\text { Rate } \\
(75-95)\end{array}$ \\
\hline $\begin{array}{l}\text { LADWP } \\
\text { PG\&E* } \\
\text { SMUD } \\
\text { SCE } \\
\text { SDG\&E }\end{array}$ & $\begin{array}{r}4,099 \\
12,983 \\
1,272 \\
10,193 \\
1,619\end{array}$ & $\begin{array}{r}4,930 \\
15,940 \\
1,560 \\
12,901 \\
2,234\end{array}$ & $\begin{array}{r}5,677 \\
18,760 \\
1,846 \\
15,864 \\
3,006\end{array}$ & $\begin{array}{l}3.3 \% \\
3.8 \\
3.8 \\
4.5 \\
6.4\end{array}$ & $\begin{array}{r}7,573 \\
24,900 \\
2,400 \\
23,288 \\
4,985\end{array}$ & $\begin{array}{l}3.1 \% \\
3.3 \\
3.2 \\
4.2 \\
5.8\end{array}$ \\
\hline TOTAL & 28,894 & 36,005 & 43,307 & 4.1 & 60,746 & 3.8 \\
\hline
\end{tabular}

* PG\&E total includes SMUD. Table 3 total adjusted to remove double counting.

Source: CERCDC, California Energy Trends \& Choices, Vol. 2, Electricity Forecasting and Planning.

The Commission has also adopted sales forecasts which are virtually identical to the peak demand forecasts; with an adopted $4.2 \%$ growth rate from 1975 to 1985 , the considered range is from $2.3 \%$ to $6.7 \%$ per year. The adopted growth rate for 1985 to 1995 is $3.8 \%$ (the range considered was 1.9 to $5.9 \%$ growth per year). SDG\&E has the highest projected growth rate, ranging from 3.3 to $7.5 \%$ per year. Table 4 displays the adopted sales forecasts. 
Table 4. Commission Adopted Sales Forecasts* (Million kWh)

\begin{tabular}{lllllll}
\hline & & & & $\begin{array}{c}\text { Growth } \\
\text { Rate }\end{array}$ & $\begin{array}{c}\text { Growth } \\
\text { Rate }\end{array}$ \\
Ut1l1ty & 1975 & 1980 & 1985 & $(75-85)$ & 1995 & $(75-95)$ \\
\hline LADWP & & & & & & \\
\hline Adopted & 18,625 & 22,898 & 26,487 & $3.6 \%$ & 36,738 & $3.5 \%$ \\
H1gh & 18,625 & 24,277 & 30,621 & 5.1 & 49,961 & 5.1 \\
Low & 18,625 & 19,630 & 19,216 & 0.3 & 20,700 & 0.5
\end{tabular}

\begin{tabular}{llllllll}
\hline PGEE*t & \\
\hline Adopted & 60,262 & 73,647 & 86,700 & 3.77 & 118,654 & $3.4 \%$ \\
E1gh & 60,262 & 81,910 & 113,709 & 6.6 & 176,288 & 5.5 \\
Low & 60,262 & 69,435 & 74,804 & 2.2 & 86,852 & 1.8
\end{tabular}

SMUD

\begin{tabular}{ccccccc}
\hline & & & & & \\
\hline Adopted & 4,411 & 5,608 & 6,902 & $4.6 \%$ & 10,005 & $4.2 \%$ \\
HAgh & 4,411 & 6,151 & 8,282 & 6.5 & 13,193 & 5.6 \\
Low & 4,411 & 5,076 & 5,538 & 2.3 & 6,244 & 1.8
\end{tabular}

\begin{tabular}{clllllll} 
SDGEE & \\
\hline Adopted & 8,141 & 10,785 & 14,500 & 5.97 & 25,041 & $5.8 \%$ \\
High & 8,141 & 14,034 & 20,032 & 9.4 & 34,456 & 7.5 \\
Low & 8,141 & 10,347 & 11,728 & 3.7 & 15,512 & 3.3
\end{tabular}

\begin{tabular}{llllllll} 
SCE & & & & & & \\
\hline Adopted & 50,108 & 64,252 & 79,157 & $4.7 \%$ & 106,174 & $3.8 \%$ \\
HIgh & 50,108 & 72,249 & 96,969 & 6.8 & 172,308 & 6.4 \\
Low & 50,108 & 58,972 & 66,842 & 2.9 & 76,449 & 2.1
\end{tabular}

IOTAL

$\begin{array}{llllllll}\text { Adopted } & 137,136 & 171,582 & 206,844 & 4.27 & 286,607 & 3.87 \\ \text { High } & 137,136 & 192,470 & 261,331 & 6.7 & 433,013 & 5.9 \\ \text { Low } & 137,136 & 158,384 & 172,590 & 2.3 & 199,513 & 1.9\end{array}$

* The utilities 1 isted account for 97.7 percent of statewide total sales. The remaining 2.3 percent are accounted for by the Calffornla Department of Water Resources, Imperial Irrigation District, Pacific Power and Light, California Pacific Utility Company, Slerra Paciffc Power Company, and Surprise Valley Electrification Corporation.

** PG\&E totals Include SMUD. Table II-1 Total adjusted to remove double counting. 
The utilities also project future growth, which in most cases will vary with the adopted forecasts of the Energy Commission. The commission has criticized the individual utilities' projections for not including non-price conservation measures, not being consistent with Department of Finance projections of households, and projecting electricity prices too low. Generally, the utilities make higher projections. The utilities are conservative in nature, are responsible for providing adequate reliable power to their customers and would prefer to play it safe by having more reserves. Table 5 displays the forecast of major utilities' electric power additions in MWe. The state forecast provides for 7,302 MWe between 1980 and 1985 ; the utilities allow for $9,880 \mathrm{MWe}$. The utilities had to cut their forecast by $26 \%$ to conform with the State Energy Commission. These forecasts are based upon planned plant capacity. Some of the plants may not be constructed and the plans will have to be revised. SDG\&E plans included the nuclear plant at sundesert, which did not receive site approval. It is possible that this planned capacity will be provided through acceleration of geothermal energy development plans.

Most of the utilities have already planned for geothernal energy on-line without the benefit of increased federal farticipation. Table 6 displays the utilities projections of geothermal electric power generation on-line, without federal assistance. A scenario of accelerated development is also displayed in Figure 3 , indicating the possible impact of federal assistance, projected by the Mitre Corporation. It is apparent that the impact of federal involvement is highly significant. Tax incentives, procedural streamlining, technology development, environmental studies, and increased planning can all have an accelerating impact on development.

One possible measure of the impact can be estimated by noting the acceleration of the projected development at Heber, California. In the time frame of one year, the plans for 
Table 5. Utility Electric Power Forecasts MHe

\begin{tabular}{|c|c|c|c|c|c|c|c|c|c|c|c|c|c|c|c|c|c|c|}
\hline Utility & 78 & 79 & 80 & 81 & 82 & 83 & 84 & 85 & 86 & 87 & 88 & 89 & 90 & 91 & 92 & 93 & 94 & 95 \\
\hline PG\&E (1) & 1,392 & 1,341 & 244 & $|1,460|$ & 1,122 & 620 & 870 & 1,160 & 1,047 & 208 & \multicolumn{8}{|c|}{ (Not Reported) $\longrightarrow \longrightarrow$} \\
\hline SCE (2) & 1,404 & 184 & 1,095 & - & 1,785 & 26 & 187 & 680 & 1,634 & 2,563 & 1,139 & 176 & 881 & 530 & 780 & 980 & 668 & 1,418 \\
\hline $\operatorname{LADWP}(3)$ & 135 & 205 & 20 & 43 & - & - & -- & 117 & -- & 220 & 797 & 128 & 248 & 148 & & & & \\
\hline SDG\&E(4) & 228 & & 496 & 176 & 44 & 176 & 487 & - & 487 & -- & 200 & 200 & 200 & 300 & - & 300 & 200 & 500 \\
\hline SMUD (5) & & & & & & 150 & & 100 & 100 & & & & & 1,100 & & & & \\
\hline NCPA (6) & & & & 264 & 88 & & 25 & 100 & & & & & & & & & & \\
\hline PWR (7) & & & & & 90 & 100 & & & 5 & & 141 & & & & & & 37.5 & \\
\hline Total & 3,159 & 1,730 & 1,855 & 1,943 & 3,129 & 1,082 & 1,569 & 2,157 & 3,273 & 2,991 & & & & & & & & \\
\hline & 3,159 & 4,889 & 6,744 & 8,687 & 11,816 & 12,898 & 14,467 & 16,624 & 19,897 & 22,888 & & & & & & & & \\
\hline
\end{tabular}
(1) PG\&E as of $3 / 78$
(2) SCE as of $3 / 78$
(3) CADWP as of $2 / 78$
(4) SDG\&E as of $3 / 78$
(5) SMUD as of $9 / 77$
(6) NCPA as of $7 / 77$
(7) PWR as of $3 / 78$

$$
\begin{array}{r}
16,624 \\
6744 \\
\hline 9,880
\end{array}
$$


Table 6. Current California Utility Geothermal Additions Forecast

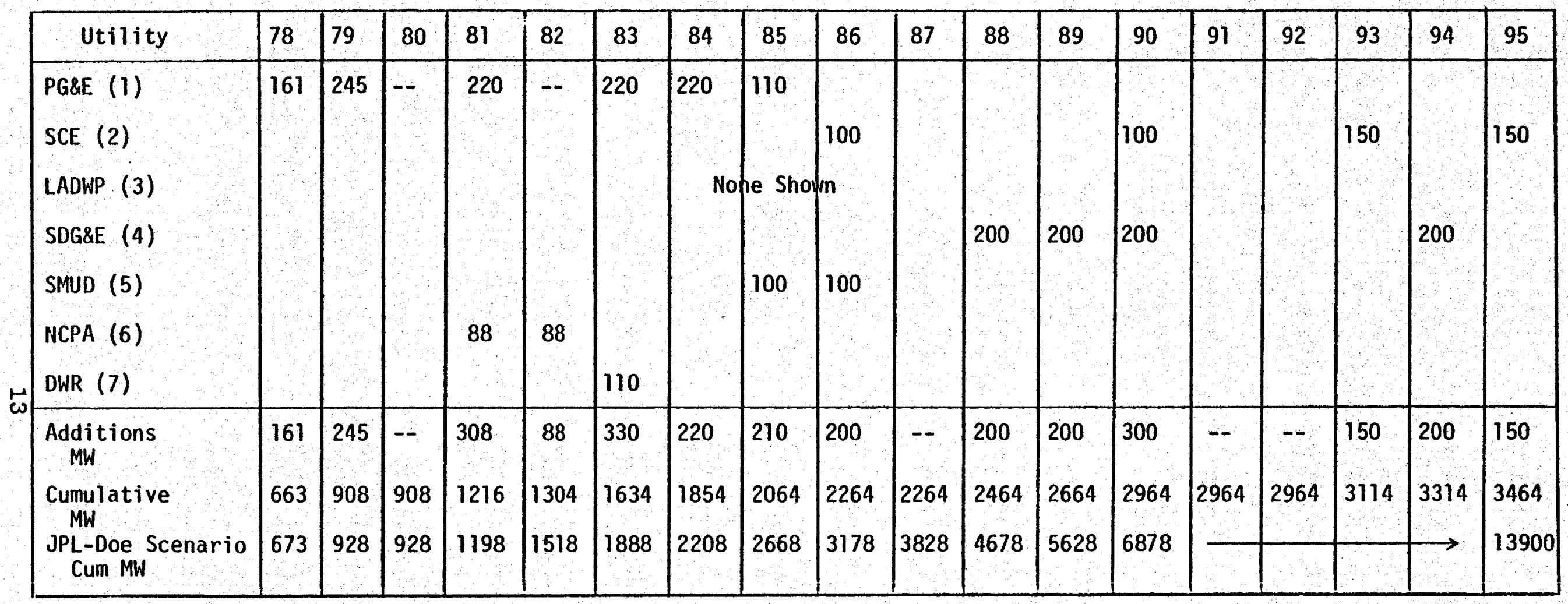
(1) PG\&E as of $3 / 78$ (Geysers steam)
(2) SCE as of $3 / 78$ (1 iquid domiziated)
(3) LADWP as of $2 / 78$
(4) SDG\&E as of $3 / 78$ ( 1 iquid domizated)
(5)' SMUD as of $9 / 77$ (Geysers steam)
(6) HCPA as of 7/77 (Geysers steam)
(7) DWR as of $3 / 78$ (Geysers steam) 


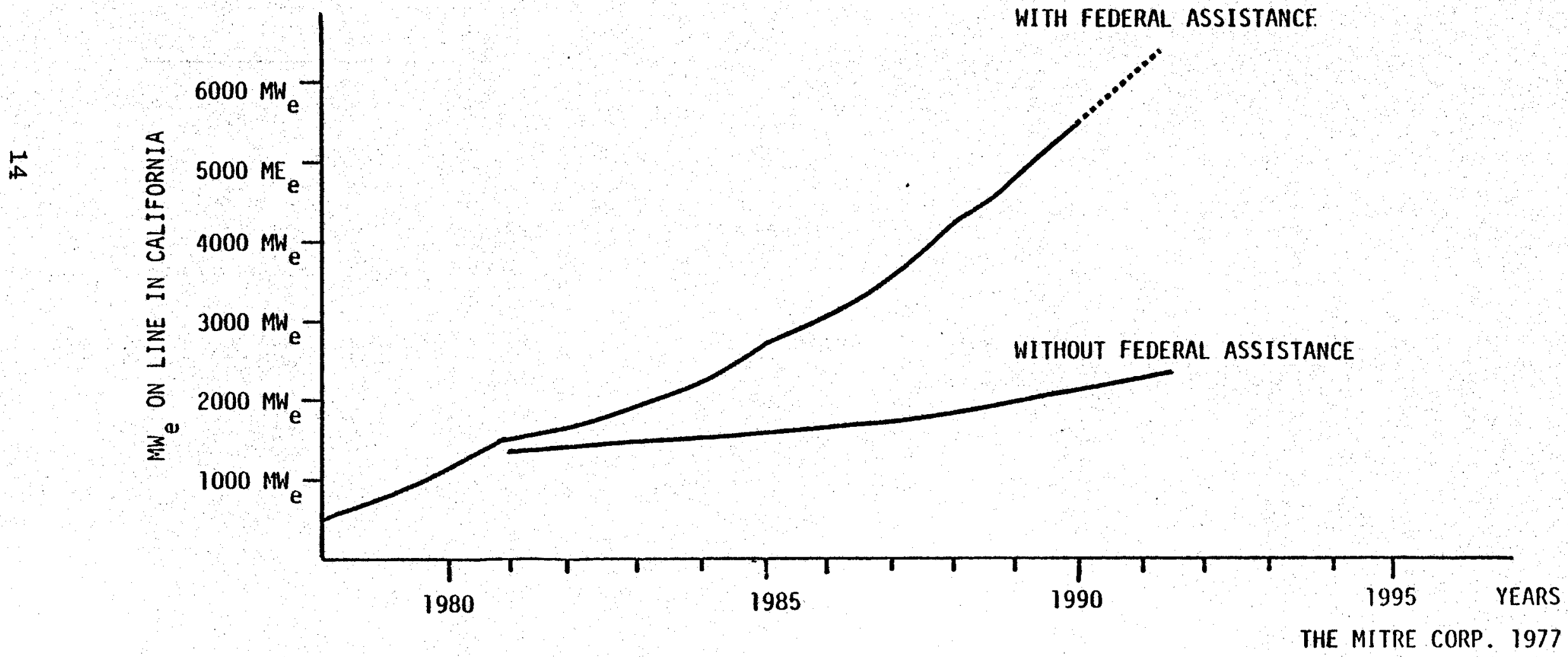

Figure 3. Projection of Geothermal Electric Power Generation In California 
geothermal development have been accelerated by one to two years. Activity in Imperial County has increased significantly and federal assistance has had a major role therein. Republic Geothermal received the first geothermal loan guaranty for a site at East Mesa. The state-of-the-art has been Improved at such facilities as the Geothermal Test Loop Facility at Niland and the DOE Geothermal Component Test Facility at East Mesa. The federal government has sponsored several research contracts including participation with the County of Imperial to develop a geothermal element to the county plan. Such activity has allowed the county to plan for development and proceed to process permitting in a soclally and environmentally secure framework. Continued federal participation can provide a catalyst to development. Figure 4 displays projections of geothermal electric energy on-line in California by the Mitre Corporation (1977), along with the updated scenario schedule prepared by SAI (1978). The acceleration in geothermal development expectations is evident upon examination of these projections, made one year apart.

The estimated busbar cost of geothermal power is an important factor in accelerating development. The more competitive the cost, the greater the development. An estimate was made of the range of costs in Imperial County for liquid-dominated resources to compare with estimates of oil, coal, and nuclear power. The "GEYSER" feasibility model was used to standardize the comparison. The parameters listed in Table 7 were used as variable inputs. Liquid-dominated geothermal appears to compare favorably with the ranges indicated, ranging from 37 to $58 \mathrm{mill} / \mathrm{kWh}$. 
Table 7. Comparison of Busbar Costs of Electric Power Using the "GEYSER" Model, Constant 1978 Dollars

\begin{tabular}{|c|c|c|c|c|}
\hline & OIL & CosL & NUCLEAR & GEOTHERMAL \\
\hline $\begin{array}{l}\text { CAPITAL COSTS } \\
\text { GENERATING PLANT }\end{array}$ & $100-600 / \mathrm{xW}$ & $700-1000 / \mathrm{KT}$ & $1000-1200 / \mathrm{kT}$ & $600-1000 / \mathrm{KT}$ \\
\hline PLANT LIEE & 30 YEARS & 30 YEARS & 30 YEARS & 30 YEARS \\
\hline LOAD FACTOR & $75 \%$ & $75 \%$ & $75 \%$ & $75 \%$ \\
\hline BTU/KWh & $8,500-10,500$ & $8,500-10,500$ & 10,160 & $21,500-32,600$ \\
\hline $\begin{array}{l}\text { FUEL COST PER } \\
\text { UILLION BTU }\end{array}$ & $\$ 2.40$ & $\$ 1.50$ & $\$ .75$ & $\$ .75$ \\
\hline CONSTRUCTION TIME & 5 Years & 5 Yenrs & 5 Years & 2 Years \\
\hline $\begin{array}{l}\text { CASH FLON } \\
\text { OF CAPITAL } \\
\text { EXPENDITURES }\end{array}$ & $\begin{array}{l}(5 \text { gr. } 20 \%) \text { or } \\
(4 \text { yr. } 12.5 \%) \\
(1 \text { yr. } 50 \%)\end{array}$ & $\begin{array}{l}(5 \text { yr. 20\%) or } \\
(4 \text { yr. 12.5\%) } \\
(1 \text { yr. } 50 \%)\end{array}$ & $\begin{array}{l}(5 \mathrm{gr} \text { a } 20 \%) \text { or } \\
(4 \mathrm{yr} \text { a } 12,5 \%) \\
(1 \mathrm{yr} \text { a } 50 \%)\end{array}$ & $(2 \mathrm{gr} \cdot \odot 50 \%)$ \\
\hline $\begin{array}{l}\text { RANGE OF } \\
\text { BUSBAR COSTS }\end{array}$ & $38-53 \times I L L / K W b$ & $38-37 \times I L L / X W b$ & $40-53 \mathrm{kILL} / \mathrm{KWb}$ & $37-58 \times 1 \mathrm{NL} / \mathrm{KTb}$ \\
\hline
\end{tabular}




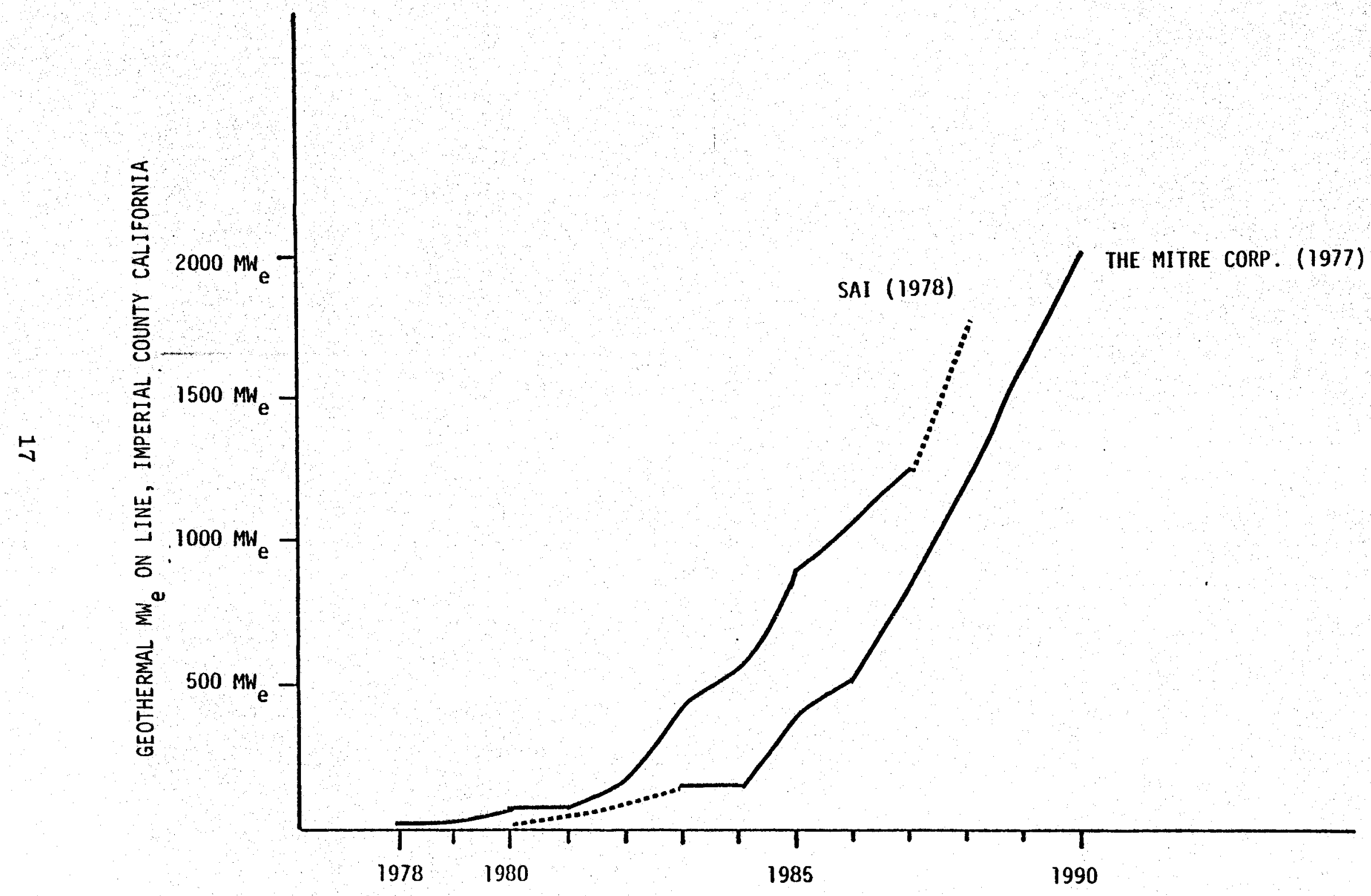

Figure 4. Comparison of Updated Scenario for Imperial County, SAI (1978) with MITRE (1977), Installed Capacity, Geothermal MW On Line 
At the present time, Hawail has sufficient power on-line to satisfy the demands of the Islands. The Hawailan Electric Company has a total estimated capability of 1,209 MWe with peak demand at approximately 900 Me. The Maui Electric Company (a subsidiary) has an estimated capability of 72 MWe with an additional 13 Me available as standby power from a pineapple plantation. Peak demand on Maui in 1976 was 67 MWe. The Hawail Electric Light Company (HELCO) has an estimated capability of 124 MWe. HELCO has contracts with two sugar companies to furnish 22 MWe of firm power. The peak demand on the Big Island of Hawaii reached 78 MWe in 1976 .

The development of additional electric power capacity in Hawali would appear to be dependent upon additional industry locating in the state. Presently HELCO is purchasing power from sugar companies at 30 mill per kWh and selling it for about two and a half times this amount. Development of geothermal power would be dependent upon the cost at which it can be supplied. Hawail is concerned with its balance of payments problem, which is impacted heavily by virtual dependence on imported oil. Geothermal energy can substitute for residual fuel oil and thus help Hawaii become energy self-sufficient and ease the BOP pressures. The Hawailan Electric Company plans to spend over $\$ 180$ mil1ion within the next five years for the Island of Oahu to develop 141 MWe of power. HELCO is planning on spending over $\$ 50$ milion during the next five years for its construction program. HGP We11 \#1, the hottest geothermal well in the world, is located in the Puna district on the Island of Hawail. A wellhead generator is being constructed which will provide approximately 5 MW of electric power. If used for direct heat application, such as sugar refining or other process heat uses, over 20 MW could be supplied. The Island of Hawail is encouraging additional Industry to locate in the area. At present, there is an unemployment problem on the Island, and an influx of industry could 
stimulate the economy. One criterion for future development, however, is that it does not interfere with the tourist business or detract from the natural beauty of the state.

As of January 1977, electric energy consumers in Hawaii were paying between 45 and 120 mills per $\mathrm{kWh}$, depending upon the usage level. Schedule "H" rates for commercial cooling, heating, air conditioning, and refrigeration service are as follows:

Capacity Charge: $\begin{gathered}\$ 2.30 \text { per month per } \mathrm{KW} \text { of required } \\ \text { capacity. }\end{gathered}$

Energy Charge:

$\begin{array}{lll}\text { First } & 100 \mathrm{kWh} \text { per month } & 12 \mathrm{mills} / \mathrm{kWh} \\ \text { Next } & 200 \mathrm{kWh} \text { per month } 89 \mathrm{mills} / \mathrm{kWh} \\ \text { Next } & 500 \mathrm{kWh} \text { per month } 64 \mathrm{mills} / \mathrm{kWh} \\ \text { All Over } & 800 \mathrm{kWh} \text { per month } 46 \mathrm{mills} / \mathrm{kWh}\end{array}$

Typical electric bills for Hawail indicate average costs ranging between $45 \mathrm{mill} / \mathrm{kWh}$ to about $87 \mathrm{mill} / \mathrm{kWh}$ for different cities, as shown in Table 8 .

Table 8. Typical Electric Bills (Residential) for Hawaii, January 1, 1977

\begin{tabular}{|c|c|c|c|c|c|c|c|c|c|}
\hline \multirow[t]{2}{*}{ crimint } & \multirow[t]{2}{*}{ nonvition } & \multicolumn{2}{|c|}{ 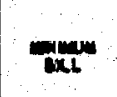 } & \multicolumn{2}{|c|}{ 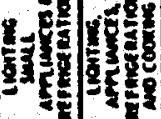 } & \multicolumn{3}{|c|}{ 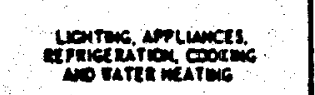 } & \multirow[t]{2}{*}{ viurt anvec cominut } \\
\hline & & namit & Ex & $x_{m}^{\infty}$ & 200 & 동 & a & ten & \\
\hline $\begin{array}{l}\text { MYYAl } \\
\text { AIEA } \\
\text { OMA Mach } \\
\text { POSTER vilLACE }\end{array}$ & $\begin{array}{l}22500 \\
2506 \\
7795\end{array}$ & $\begin{array}{|cc|}3 & \\
2 & 70 \\
2 & 90 \\
2 & 90 \\
2 & 70\end{array}$ & $\begin{array}{l}24 \\
24 \\
24 \\
24\end{array}$ & $\begin{array}{r}1 \\
102 \\
02 \\
02 \\
02 \\
0.02\end{array}$ & $\begin{array}{lll}1 & \\
13 & \text { is } \\
\text { is } & \text { is } \\
\text { is } & \text { is } \\
\text { is } & \text { is }\end{array}$ & $\begin{array}{ll}25 & 00 \\
25 & 00 \\
25 & 01 \\
25 & 09\end{array}$ & 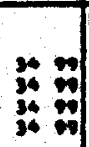 & of 87. & 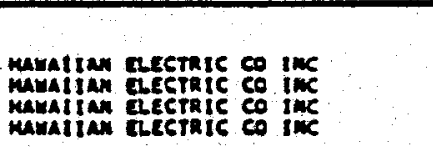 \\
\hline 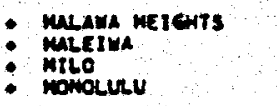 & $\begin{array}{r}100 \\
2826 \\
324 \\
393 \\
811\end{array}$ & $\begin{array}{ll}2 & 70 \\
2 & 70 \\
3 & 80 \\
3 & 70\end{array}$ & $\begin{array}{l}24 \\
24 \\
24\end{array}$ & $\begin{array}{l}0.02 \\
8 \\
13 \\
102 \\
02\end{array}$ & $\begin{array}{ll}25 & 25 \\
13 & 25 \\
23 & 24 \\
13 & 25\end{array}$ & 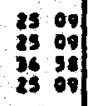 & $\begin{array}{ll}34 & 90 \\
34 & 9 \\
34 & 90\end{array}$ & $\begin{array}{ll}\text { is } & 28 \\
\text { is } & 27 \\
\text { is } & \text {.7 } \\
\text { is } & 29\end{array}$ & 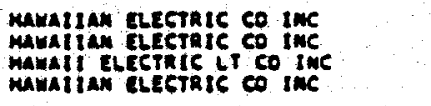 \\
\hline 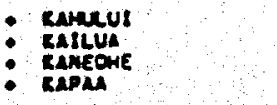 & $\begin{array}{c}210 \\
280 \\
294\end{array}$ & $\begin{array}{lll}3 & 10 \\
2 & 70 \\
3 & 90 \\
3 & 40\end{array}$ & $\begin{array}{l}24 \\
24 \\
25\end{array}$ & $\begin{array}{l}10.0 \\
802 \\
10 \\
102\end{array}$ & 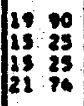 & $\begin{array}{ll}32 & 00 \\
25 & 08 \\
85 & 80 \\
17 & 81\end{array}$ & 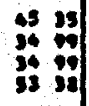 & $\begin{array}{ll}3 & 60 \\
4 & 29 \\
4 & 29 \\
8 & 82\end{array}$ & 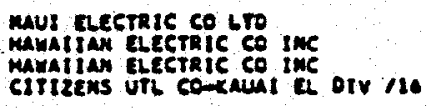 \\
\hline $\begin{array}{l}\text { Lanatixa } \\
\text { Hife } \\
\text { Lime } \\
\text { Lill }\end{array}$ & $\begin{array}{l}140 \\
124 \\
397\end{array}$ & $\begin{array}{ll}3 & 30 \\
3 & 70 \\
3 & 40 \\
1 & 10\end{array}$ & $\begin{array}{l}24 \\
23 \\
24\end{array}$ & $\begin{array}{ll}10 & 10 \\
10 & 77 \\
102 & 02\end{array}$ & $\begin{array}{l}10 \text { is } \\
\text { is is } \\
21 \\
\text { is } 25\end{array}$ & \begin{tabular}{ll|}
2 & on \\
is & 09 \\
is & 00
\end{tabular} & 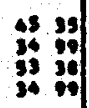 & 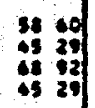 & 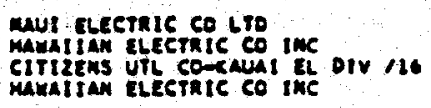 \\
\hline 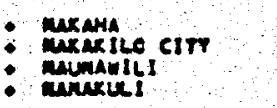 & $\begin{array}{l}\cos \\
\operatorname{sos} \\
\sec \end{array}$ & $\begin{array}{ll}1 & 10 \\
2 & 10 \\
2 & 70 \\
2 & 70\end{array}$ & $\begin{array}{l}24 \\
24 \\
24\end{array}$ & $\begin{array}{l}.92 \\
8.2 \\
82\end{array}$ & $\begin{array}{l}\text { is } 15 \\
\text { is } 25 \\
\text { is } 25 \\
\text { is } 25\end{array}$ & \begin{tabular}{ll|}
25 & 0 \\
25 & 0 \\
25 & 0.1
\end{tabular} & $\begin{array}{cc}34 & 94 \\
34 & 90 \\
34 & 90\end{array}$ & $\begin{array}{ll}45 & 22 \\
45 & 27 \\
4 & 22 \\
4 & 20\end{array}$ & 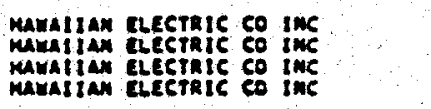 \\
\hline 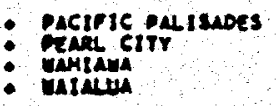 & 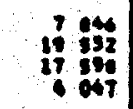 & $\begin{array}{ll}2 & 10 \\
8 & 10 \\
2 & 70 \\
1 & 10\end{array}$ & $\begin{array}{l}24 \\
24 \\
24 \\
24\end{array}$ & $\begin{array}{c}82 \\
02 \\
02 \\
02\end{array}$ & 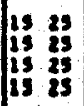 & $\begin{array}{ll}25 & 00 \\
23 & 00 \\
25 & 04 \\
25 & 09\end{array}$ & 34 & 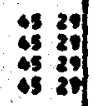 & 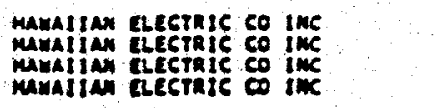 \\
\hline 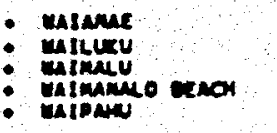 & 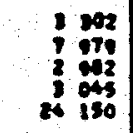 & \begin{tabular}{ll|}
2 & 10 \\
3 & 80 \\
2 & 10 \\
2 & 90 \\
2 & 10
\end{tabular} & $\begin{array}{l}20 \\
24 \\
24\end{array}$ & $\begin{array}{r}102 \\
10.02 \\
02 \\
02 \\
02\end{array}$ & $\begin{array}{ll}\text { is } & 25 \\
19 & 90 \\
\text { is } & 25 \\
\text { is } & 25 \\
\text { is } & 25\end{array}$ & \begin{tabular}{ll|}
23 & 90 \\
32 & 0 \\
23 & 09 \\
is & 00 \\
is & 01
\end{tabular} & $\begin{array}{ll}3 & 0 \\
4 & 39 \\
4 & 9 \\
3 & 0\end{array}$ & $\begin{array}{ll}4 & 28 \\
34 & 80 \\
4 & 29 \\
4 & 89\end{array}$ & 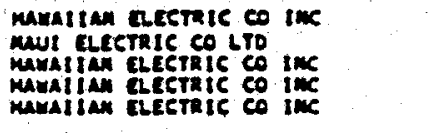 \\
\hline
\end{tabular}


Fuel costs have been escalating in Hawail over the last five years, from 50 cents per million BTU $(\$ 3.25 / \mathrm{bb} 1)$ in 1971 to over $\$ 2.00$ per million BTU in 1977 ( $\$ 2.18$ per million BTU at $\$ 12 / \mathrm{bbl})$. Hawail presently derives $92 \%$ of 1 ts energy from imported fuel oil. As the price of oil escalates (over $\$ 500$ million annually), an increasing burden is placed upon Hawaii's balance of payments. Uncertainty with regard to future energy costs increases geothermal energy's desirability as a substitute. 


\section{DIRECT USE OVERVIEW OF CALIFORNIA (SUMMARY)}

In the process of developing the Direct Use Overview for California, a model was developed to estimate the demand for direct heat applications of geothermal energy. Data on existing demographic and business patterns were input to project the local potential demand for geothermal heat. The potential uses were correlated with conservative estimates of the potential geothermal resources to achieve a statistical estimate of the volume of resource exploitation which might be achieved.

Most of the Known Geothermal Resource Areas (KGRA's) in California are located in areas remote from many of the potential resource users. The KGRA's were established anticipating high-quality energy usage such as electric power generation. Many direct use applications do not require the higher temperatures associated with electric power generation.

It is estimated that there is a substantial level of lower quality geothermal resources which are located near urban markets. Figure 5 on the following page displays unexplored resource areas whose hot springs and geologic characteristics -ndicate historical and potential resources. Although the estimates of electric power potential in areas other than the KGRA's are limited, possibilities exist for process heat and space heating. An exploration program to better define the resources avallable to potential direct heat users is essential to verify the resource, if large amounts of direct use are to be developed. The estimates cited for this market analysis are conservative, based upon low probabilities of resource exploitability. Resource confirmation could increase these probabilities substantially. Demonstration of cost-effective applications of direct use of geothermal energy is the strongest marketing tool that could be used to accelerate direct use development. 


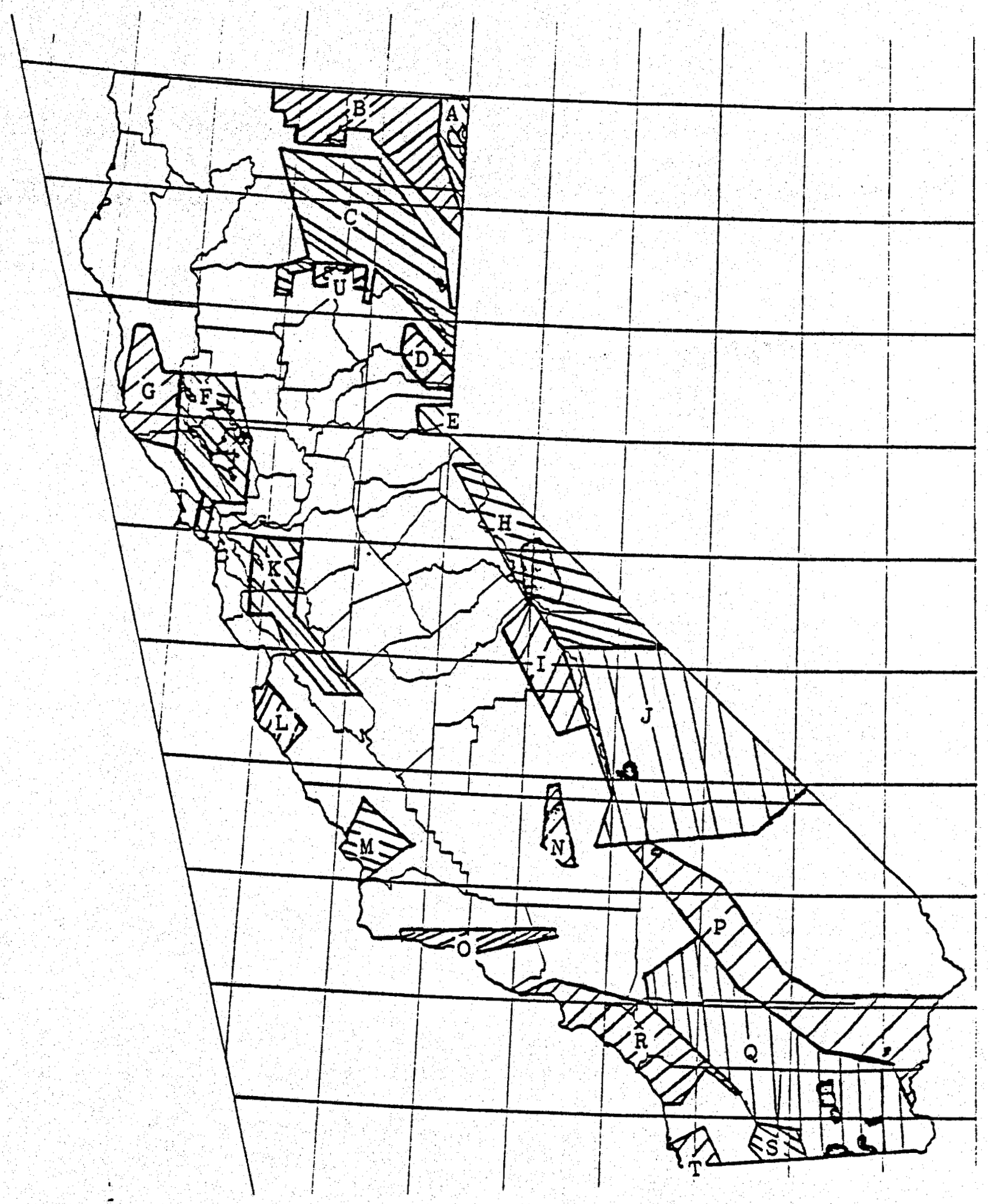

Figure 5. Resource Zones from the Direct Use Overview 
Estimates of the potential level of usage or market demand were made by using an evaluative process point system of resource indicators. Resource areas were assigned points on the basis of the presence of surface evidence of resources and the presence of potential users. Equal weight was given to resource indicators and user (or market) indicators. Points were assigned for such factors as the presence of thermal wells and springs, surface temperatures, heat flow, population, concentration of industry and agriculture. (A description of the point system is given in the Direct Use Overview).

The more highly populated the area, the greater the market potential. The evaluative process described above highlights areas such as Los Angeles, Long Beach, Santa Barbara, San Luis Obispo, San Diego, and Contra Costa and Santa Clara Counties as focal points for geothermal energy exploration. Markets are given an important weighting. The presence of a market is a crucial consideration in planning for the accelerated growth of geothermal energy, because the energy generally cannot be transported over great distances. Piping of geothermal fluids to distances of over 50 miles is unlikely due to heat $10 s s$, Iriction in the system and excessive capital costs. Demonstrations of geothermal energy in isolated, remote areas are valuable, but the chances of accelerated development in these areas are much lower than in urban and suburban districts.

The geothermal energy discovered to date tends to be located where there are very limited direct use markets. An exploration program for direct use potential should first assess the market possibilities. Even if there is a higher likelihood of flnding geothermal resources in rural areas, there is no benefit if a market does not exist for the resource. A balance must be reached between the risk of not finding a resource and the risk of very limited markets. The amount of direct heat utilization, then, is based upon the premise that substantial 
direct use development will only be achieved where resources and potential heat applications co-exist.

An overview of the energy usage levels that could be achieved in the near-term for space conditioning and industrial process heating was performed. The result is a conservative estimate of the level of direct use that could be achieved immediately, given sufficient investment. Demand for residential (district) space heating was not considered. Nine groups of applications were considered:
1. hospitals
2. colleges and universities
3. hotels
4. food processors
5. 1 umber milis
6. paper and pulp manufacture
7. chemicals and allied products
8. petroleum and coal products
9. rubber and miscellaneous plastics

This list does not include all of the possibilities for direct heat applications but does represent some of the major candidates for market development in order to make conservative estimates of direct use viability.

Geothermal resource zones were defined in which geothermal resources have been indicated. The zones are displayed in Figure 5. The zone generally includes the areas labeled as "prospective resource areas" by USGS, but additional areas have been included since some of the direct uses under consideration can be served with relatively low temperatures. Some isolated thermal springs existing outside the zone were not considered. 
Each zone was assigned a probability, indicating the chance of finding a resource at a given location for three temperature classes., Then, given

$$
\begin{aligned}
\mathrm{X}_{\mathrm{CA}} & =\text { the number of applications of type } A \text { in county } \mathrm{C} \\
\mathrm{P}_{\mathrm{Z}, \mathrm{T}} & =\text { the probability by zone and temperature } \\
\mathrm{Z} & =\text { zone } \\
\mathrm{A} & =\text { applications } \\
\mathrm{C} & =\text { county } \\
\mathrm{E} & =\text { energy use required for application }
\end{aligned}
$$

then

$\sum_{Z A C} \sum_{Z}, T^{X_{Z}}, C, A_{C A}=$ estimated developable usage by a 11 ZAC applications.

This estimate is $10^{14} \mathrm{BTU} / \mathrm{yr}$ or 0.1 quads. It was estimated that about 450 wells would be needed (assumed pumped, at an average rate of $1,000 \mathrm{gpm}$, at a cost of $\$ 500$ million to develop the wells and distribution systems. Assuming the competitive cost of fuel is presently $\$ 2$ per million BTU, private industry would be wiling to put up only 25 percent of the capital investment at the present time. This, however, does not mean that geothermal energy is not cost-competitive, because the applications mentioned would consume only about 11 percent, on the average, of the total energy provided. Cascading effects, once the resources are established, would enhance the efficiency of usage and could easily make the resource viable. Also, many applications would already be efficient, using 80 to 90 percent of the total energy recoverable. Figure 6 displays an estimate of the expected number of BTU's on-line, given increasing levels of capital investment. 


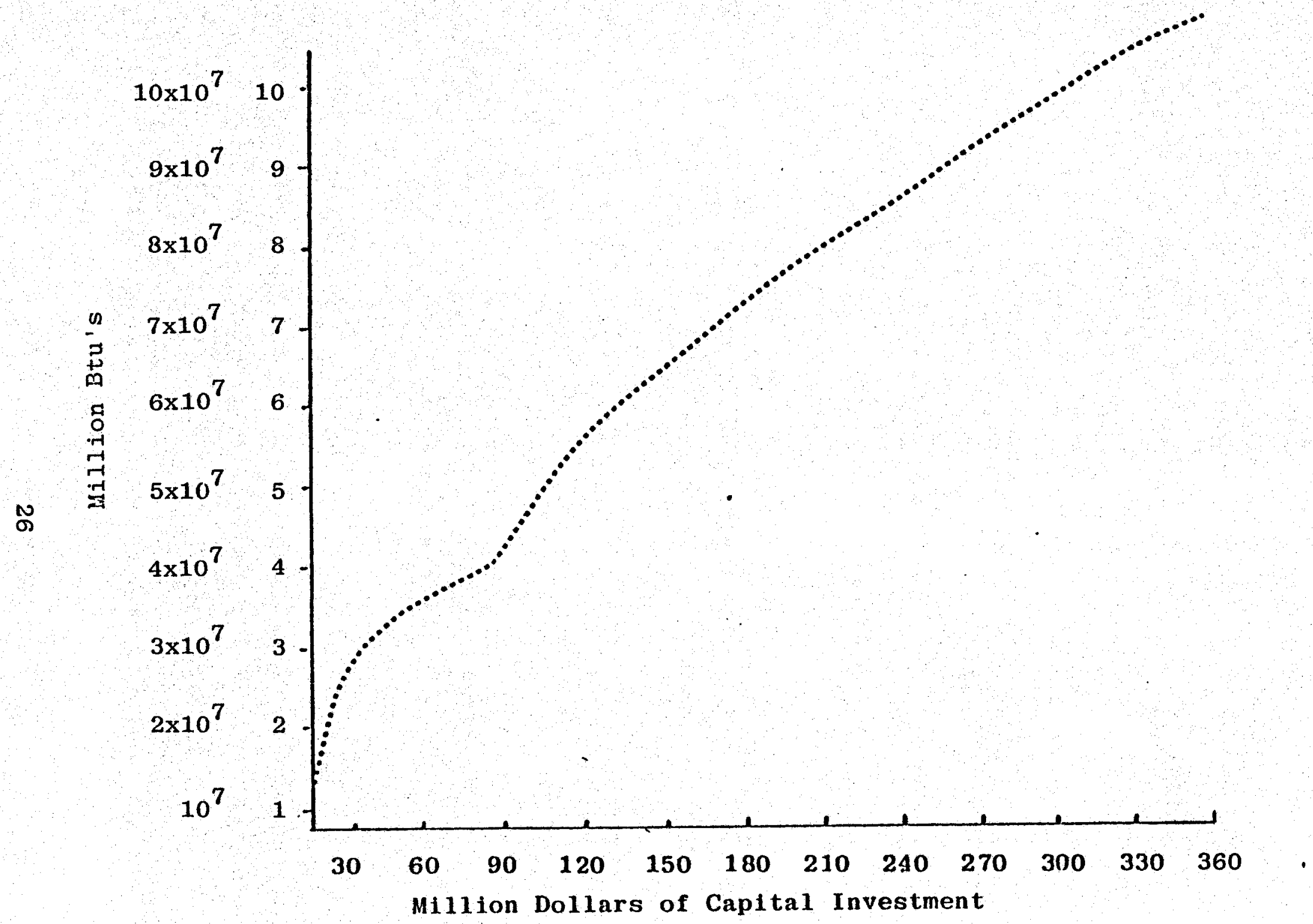

Figure 6. BTU's in Production Resulting from Capital Investment 


\section{MARKET FOR DIRECT HEAT APPLICATIONS}

The market analysis for the Direct Heat Applications of geotbermal energy for California must be generalized to a large extent because of the volume of business activity presently taking place in the state. With fifty-eight counties in the state and hundreds of cities, it is a substantial task to attempt a detalled study of specific markets for individual goods and services. There are three major categories of direct heat applications which are under consideration. They are:

- Space Conditioning (heating and cooling)

- Agribusiness (agriculture and aquaculture)

- Industrial Use (process heat and mechanical work)

5.1.1 Space Conditioning

In order to use geothermal resources for space heating, temperatures of $80^{\circ} \mathrm{F}$ must be attained. All of the Known Geothermal Resource Areas (KGRA) in California are capable of providing $80^{\circ} \mathrm{F}$ water for space heating. A question arises as to need and economics. In Southern California the climate is moderate and the demand for space heating is very low. In Imperial County, where vast amounts of geothermal energy exist, the temperatures reach $100^{\circ} \mathrm{F}$ over 100 days out of the year. Space cooling needs are greater in Southern California and the air cooling systems have higher temperature requirements. Refrigeration technologies utilizing geothermal fluids are presentiy in the process of being developed. An economical system has yet to be demonstrated In the U.S. Utilization of geothermal fluids for a refrigeration or cooling system is technically feasible, however, economic systems have not been demonstrated. 
Space heating is expected to be developed to a greater extent than space cooling in the near-term and will be a function of heating degree days and population. Heating degree days in Northern California range from $2000^{\circ} \mathrm{C}$ to $4000^{\circ} \mathrm{C}$, while they vary between $1000^{\circ} \mathrm{C}$ to $2000^{\circ} \mathrm{C}$ in southern California. This means that 1n Northern California, on the average, the temperature must be raised between $5.5^{\circ}$ and $11^{\circ} \mathrm{C}$ each day. In Southern California, the temperature must be raised between $2.7^{\circ} \mathrm{C}$ and $5.5^{\circ} \mathrm{C}$ each day.

Economies of scale impact the potential for space heating for many resources. A deep well is prohibitive for a smal1 household or business. Where the resources require rotary drill rigs, a district heating system would be necessary to make the project ecoponical. Such an application might include an Industrial park, a large housing or apartment complex, or a serles of office buildings and would most likely be required in areas with bigh population densities. Urban, rather than rural areas, would also be more likely to be developed.

Looking at Figure 5 , an output of the direct use overview which displays the potential direct use resource areas, it appears that Areas $G, F, K$, and $L$ would have the highest potential for a district heating system. Areas $A, B, C, D$ and $E$ in the northeastern portion of the state have the greater heating degree days, however the population density in this area is very low. Space heating might be developed here if the geothermal wells are shallow (less than 1,000 feet), similar to the wells in Klamath Falls, Oregon.

\subsubsection{Agribusiness}

California leads the nation in the production of forty-four commercial crop and livestock commodities. A wide range of crops is produced with no one crop dominating the state's agricultural economy. Geothermal energy can be used to heat greenhouses, heat crop lands, and for food processing 
(dehydration and canning, and potentially for freezing or coollng). Table 9 displays California's share of national agricultural commodities production, along with its national ranking. One important factor to note is that most of the crops have relatively short harvest seasons. This indicates that a food processing plant would require more than one crop for production. Some major crops grown in California which might be likely candidates for utilization of geothermal energy are Included in Table 10 along with their respective harvest seasons. Major processing already exists for asparagus, snap beans, green peas, spinach, strawberries, and tomatoes.

Since many of the harvest seasons for crops are relatively short (three months or less), it may be necessary to combine two, three, or four crops into a processing cycle in order to increase the load factor of the processing plant. For example, one likely candidate application is dehydration of onions. The harvest season for onions is from April through October, seven months. The processing season would be even shorter, two to three months. In order to justify the capital expenditure of a dehydration plant it would be necessary to keep the plant in operation 9 to 12 months out of the year carrots and potatoes are grown continuously throughout the year and could fick up slack time in the plant. Celery and bell peppers could also be candidates for application. Dehydration temperature requirements are approximately $100^{\circ} \mathrm{C} \quad\left(212^{\circ} \mathrm{F}\right)$. The value of shipments of dried and dehydrated fruits and vegetables (soup mixes, etc.) increased $7 \%$ for the nation from 1976 to 1978 ; market expectations for 1978 project an $8 \%$ increase. This would indicate that real production is expected to incease one to $2 \%$ for the nation in the coming year. Dehydrated goods are light in weight and can easily be shipped throughout the country. In 1970, there were ninety-eight businesses with 5,274 employees in the food drying and dehydration business and in 1975, there were seventy-nine, with 5,389 employees. It would appear that there has been excess capacity in the state and smaller firms have 
Table 9. National Ranking, Share of Production, and Harvested Acreage for California's Commodities

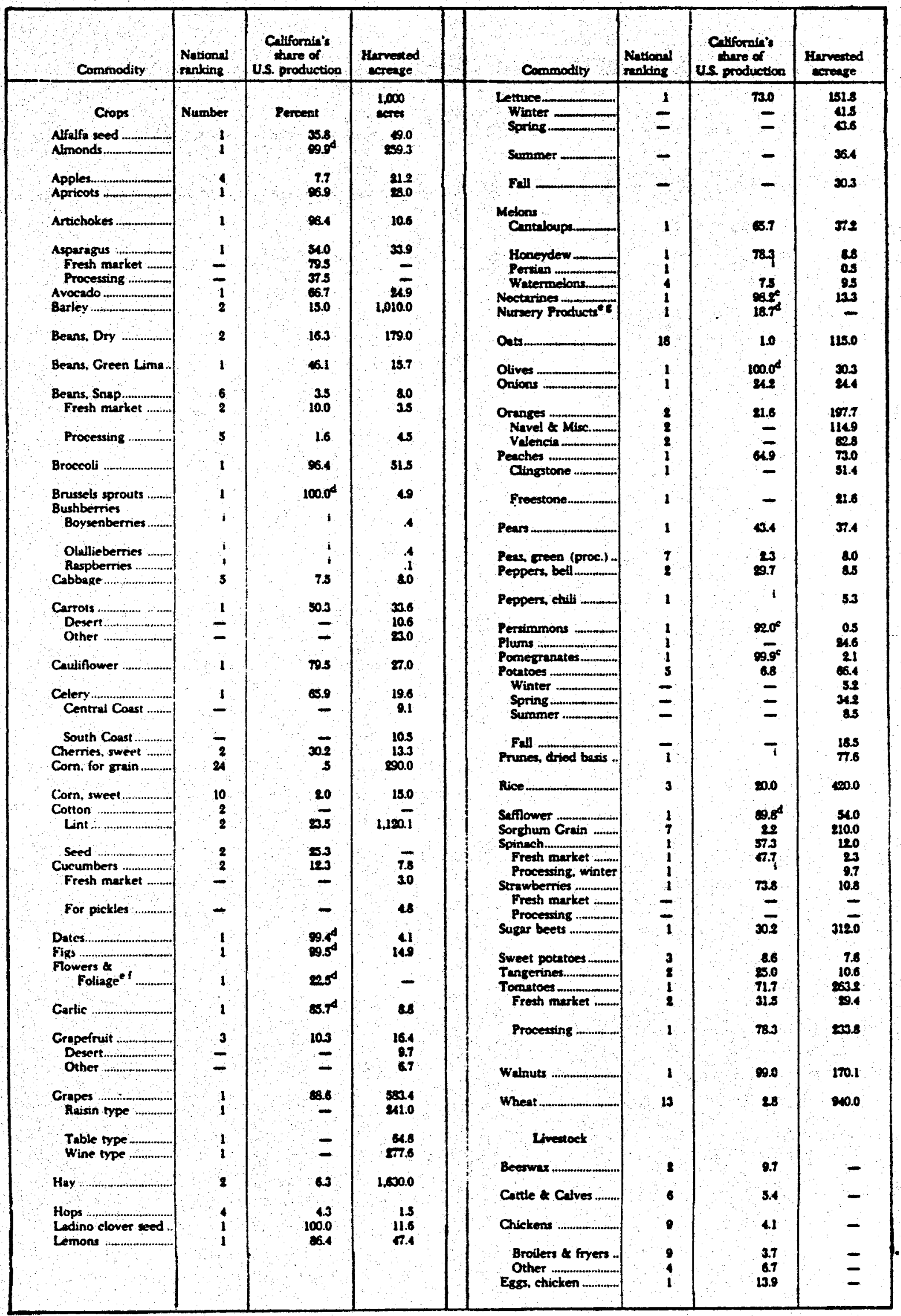


Table 10. Harvest Seasons for California Crops

\begin{tabular}{|c|c|c|c|c|c|c|c|c|c|c|c|c|c|c|c|c|c|c|c|c|c|c|c|c|c|}
\hline & 紊 & 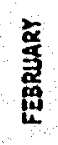 & 焉 & $\vec{a}$ & $\frac{2}{2}$ & 崖 & 3 & $\frac{5}{\mathrm{~g}}$ & 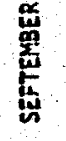 & $\begin{array}{l}\text { 总 } \\
\text { 惫 } \\
\text { 吾 }\end{array}$ & $\begin{array}{l}\text { 总 } \\
\text { 墨 } \\
\text { 尊 }\end{array}$ & $\begin{array}{l}\text { 总 } \\
\text { 惫 } \\
\text { 岁 }\end{array}$ & & $\frac{\sqrt{3}}{\frac{3}{5}}$ & 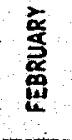 & 章 & $\begin{array}{l}\overrightarrow{\vec{\alpha}} \\
\vec{\alpha}\end{array}$ & $\overline{\mathbf{z}}$ & 崖 & 5 & $\frac{\bar{c}}{\mathrm{z}}$ & 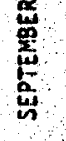 & 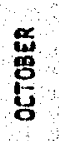 & $\begin{array}{l}\stackrel{\mathbf{a}}{\mathbf{w}} \\
\frac{\mathbf{w}}{\mathbf{z}}\end{array}$ & 惹 \\
\hline & & & & & & & & & & & & & Ladlino Clover Seed & & & & & & & & - & $\div$ & $\bullet$ & & \\
\hline $\begin{array}{l}\text { CROPS } \\
\text { Alfalfo seed }\end{array}$ & & & & & & & & $\bullet$ & $\bullet$ & $\bullet$ & & & Lemons & 1 & - & $\div$ & - & $\div$ & - & $\div$ & 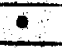 & & & & \\
\hline Almands & & & & & & & & $\div$ & $\div$ & 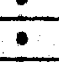 & & & Lettuce: $\begin{array}{c}\text { Ninter } \\
\text { Spring }\end{array}$ & - & $\bullet$ & $\bullet$ & - & - & - & & & & & & \\
\hline Apples & & & & & & & $\div$ & $\div$ & $\div$ & - & & & $\begin{array}{l}\text { Sumper } \\
\text { fall } \\
\end{array}$ & & & & & & & $\bullet$ & $\cdot$ & $\cdot$ & $\bullet$ & - & - \\
\hline Apricots & & & & & & - & - & $\div$ & & & & & Cantaloups & & 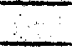 & & 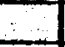 & - & - & $\bullet$ & - & $\because$ & $\div$ & 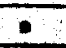 & \\
\hline ArtIchokes & - & - & $\bullet$ & $\div$ & $\div$ & - & - & - & $\bullet$ & - & - & - & Honeydew & & & & & - & & $\bullet$ & 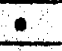 & - & $\cdot$ & - & \\
\hline $\begin{array}{l}\text { Asparagus: Fresh } \\
\text { Processing }\end{array}$ & & $:$ & $:$ & $:$ & $:$ & $:$ & & & & & & & Persian & 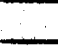 & & & 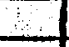 & - & 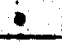 & $\bullet$ & $\bullet$ & $\bullet$ & - & & \\
\hline Avocado & $\bullet$ & $\bullet$ & $\bullet$ & $\div$ & $\div$ & $\div$ & - & $\div$ & & & 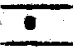 & $\div$ & Hatenuelons & & 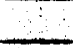 & & $\therefore$ & $\bullet$ & - & $\bullet$ & - & - & $\bullet$ & & \\
\hline Barley & & 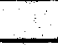 & & 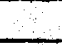 & & - & $\bullet$ & - & & 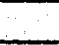 & 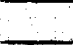 & E & Hectarines: & - & 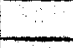 & 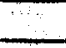 & - & 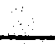 & $\therefore$ & - & $\bullet$ & - & 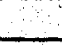 & 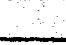 & \\
\hline Beans, Dry & & - & & $\cdots$ & 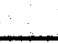 & 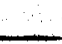 & - & - & - & - & - & 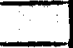 & Mursery Proflucts & & & & & & & & & & - & - & \\
\hline Beans, Green lima & & & & & & & & $\div$ & $\div$ & $\div$ & & & Oats & & - & & 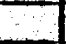 & 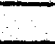 & $\cdot$ & $\div$ & $\div$ & 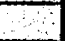 & $y$ & 3 & \\
\hline Beans. Snap: fresh & & & & $\cdot$ & $\cdot$ & - & 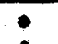 & ! & $!$ & 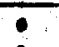 & $\because$ & $?$ & Olives & - & - & 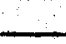 & 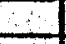 & - & - & 5 & 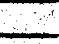 & $\square$ & 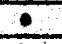 & $\div$ & 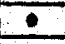 \\
\hline Processing & & & & & & & 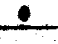 & $\stackrel{\bullet}{\circ}$ & $\therefore$ & 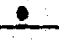 & & & Onions & & & & $\bullet$ & - & - & $\bullet$ & - & $\bullet$ & $\bullet$ & & 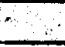 \\
\hline$\frac{\text { Broccoll }}{\text { Brussels sprouts }}$ & $\div$ & $\div$ & $\div$ & - & 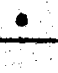 & - & $\div$ & $\div$ & $\div$ & $\frac{\bullet}{9}$ & $\div$ & $\div$ & $\begin{array}{r}\text { Oranges: Maval } \\
\text { Yalencia }\end{array}$ & $?$ & $\bullet$ & $\bullet$ & - & $\bullet$ & & $\ldots$ & a & 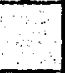 & 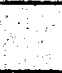 & $\because$ & $\bullet$ \\
\hline Boysenberrles & 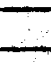 & & & & & $\div$ & & & & & & & $\begin{array}{c}\text { Peaches: Cllngstone } \\
\text { Freestone }\end{array}$ & & & & & & - & $:$ & 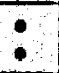 & : & & & \\
\hline D1allieberrles: & & _ & & & & $\because$ & $\because$ & 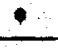 & & & & 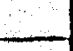 & Pears & & & & & & & $\div$ & $\div$ & - & & & \\
\hline Raspherries & & & & & & $\bullet$ & - & & 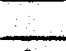 & 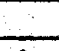 & & & Peas, green & & & & 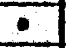 & $\cdot$ & - & & & & & & \\
\hline Cabbaye & - & $\because$ & $\because$ & $\bullet$ & $\bullet$ & $\div$ & $\bullet$ & $\div$ & - & - & $\because$ & $\div$ & Peppers, bell & & & & & & - & $\bullet$ & - & - & $\bullet$ & $\div$ & $\bullet$ \\
\hline $\begin{array}{r}\text { Carrots: } \text { nesert } \\
\text { Olper } \\
\end{array}$ & $\because$ & $:$ & $:$ & $\vdots$ & $\vdots$ & $:$ & $\because$ & $\vdots$ & $!$ & $!$ & $\vdots$ & $\vdots$ & Peppers, chilli & & & & & 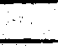 & 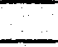 & 5 & + & $\cdot$ & - & $\div$ & $\cdot$ \\
\hline Cauliflower & $\Leftrightarrow$ & $\bullet$ & - & $\bullet$ & $\div$ & 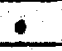 & 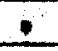 & $\cdot$ & $\bullet$ & $\bullet$ & 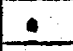 & $\bullet$ & Perslmons & & & & . & 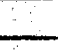 & 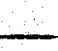 & + & 3 & $\bullet$ & $\bullet$ & $\bullet$ & $\bullet$ \\
\hline Celery: Central & & & & & & & & & & & & & Plums & & & & & - & - & $\bullet$ & - & 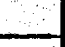 & $\cdots$ & 3 & \\
\hline $\begin{array}{l}\text { South Coast } \\
\end{array}$ & & & & $:$ & $:$ & $?$ & $\vdots$ & : & ! & ? & $:$ & : & Pomegranates & & & & & 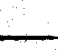 & - & $\square$ & 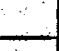 & $\bullet$ & 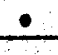 & $\bullet$ & \\
\hline Cherriles, Sweet & 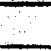 & & & - & $\bullet$ & $\div$ & & & & & & & 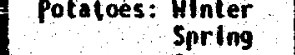 & $?$ & $\bullet$ & $\bullet$ & $:$ & - & $\because$ & - & $\bullet$ & 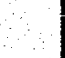 & & & \\
\hline Carn, for grain & & & 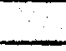 & & & & & & $\because$ & $\div$ & 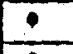 & & Summer & $\bullet$ & $\bullet$ & . & & & - & - & 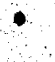 & $:$ & $:$ & $\bullet$ & - \\
\hline Corn, smeet & & & - & 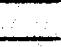 & $\div$ & - & $\div$ & 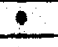 & $\because$ & $\therefore$ & $\div$ & $\because$ & Prunes, drled & & & & & 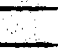 & 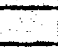 & 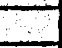 & $\bullet$ & $\cdot$ & & & \\
\hline Cotten, $\operatorname{lint}_{\text {seed }}$ & & & & & & & & & - & - & & & Aice & & 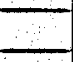 & & & - & 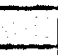 & 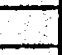 & 3 & - & 0 & $\circ$ & \\
\hline Cucumbers: Fresh & & & 0 & 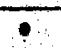 & - & 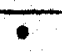 & $\div$ & $\bullet$ & $\because$ & 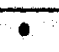 & $\bullet$ & & Safflower & & & 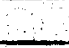 & & 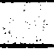 & & 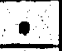 & $\div$ & $\bullet$ & & 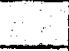 & \\
\hline For pickles & & & & & & & $\bullet$ & - & - & & & & Sorghtum frala & & & & & 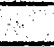 & - & + & - & $\bullet$ & 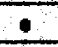 & $\cdot$ & 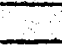 \\
\hline mates & & & & & & $\cdot$ & 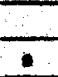 & $\cdot$ & & $\div$ & 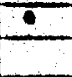 & 9 & $\begin{array}{l}\text { Splnach: Fresh } \\
\text { Processing. winter }\end{array}$ & - & $\bullet$ & $\vdots$ & $:$ & $:$ & - & $\bullet$ & 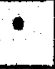 & $\bullet$ & $?$ & $\bullet$ & - \\
\hline Flowers \& fol laye & & & & 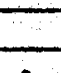 & 0 & & 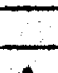 & 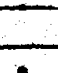 & 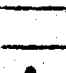 & 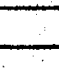 & - & & $\begin{array}{c}\text { Seramberrles: fresh } \\
\text { Processing }\end{array}$ & & 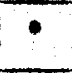 & - & $\bullet$ & - & $\because$ & $\div$ & $\bullet$ & $\bullet$ & $\bullet$ & $\bullet$ & \\
\hline Garlfe & & & & - & - & - & $\bullet$ & 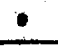 & $\bullet$ & & & & Sugar beets & & & & $\cdot$ & - & $\cdot$ & . & $\bullet$ & - & $\div$ & $\cdot$ & $\bullet$ \\
\hline $\begin{array}{c}\text { Grapefruit: Desert } \\
\text { Other }\end{array}$ & $\bullet$ & $\bullet$ & $\bullet$ & - & $:$ & - & $\bullet$ & - & & & & & Sweet potatoes & & & & & & & $\div$ & $\bullet$ & $\bullet$ & 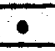 & $\because$ & \\
\hline & & & & & & & $\because$ & $\because$ & 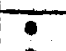 & $?$ & & & Iangarlnes & $\div$ & $\bullet$ & $\div$ & - & & & & & & & & $\cdot$ \\
\hline $\begin{array}{r}\text { Table type } \\
\text { Mine type } \\
\end{array}$ & & & & & & - & - & - & $:$ & 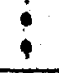 & - & & $\begin{array}{l}\text { Tomaloes: Fresh } \\
\text { Processing }\end{array}$ & & & & - & 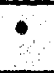 & $:$ & $:$ & $:$ & $:$ & $:$ & $\because$ & $\cdot$ \\
\hline Hay & & & $\bullet$ & $\div$ & 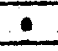 & $\div$ & 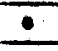 & $\div$ & $\div$ & $\div$ & . & & Malnuts & & & & & 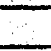 & $\therefore$ & 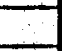 & 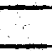 & $\cdot$ & 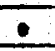 & $\bullet$ & \\
\hline Hops & & & & & & & & 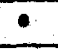 & $\because$ & & & & theat & & & & & & $\therefore$ & $\bullet$ & - & & & & \\
\hline
\end{tabular}


dropped out of the market. The competitive nature of the geothermal resource 111 determine if retrofitting or a new plant wth locational benefits would be in order.

\subsubsection{Industrial Uses}

There is a wide variety of industrial uses for process heat. In order to determine the market for process heat in California a county-by-county compilation of energy use was made. The following six major industries were considered:

SIC CODE

20

24

26

28

29

30
INDUSTRY

Food \& Kindred Products

Lumber \& Wood

Paper \& Allied Products

Chemicals \& Allied Products

Petroleum \& Coal Products

Rubber \& Misc. Plastics

These six industries consume the major portion of the process heat used in the state.

To estimate county markets, three market indicators were used for the above industries. They are: 1) yearly energy use per capita, 2) yearly total energy use per county, and 3) yearly energy use per square mile. These statistics are displayed in Figures 7 through 9 for each county. Total energy usage gives an Indication of the volume of energy used, Energy Per Capita gives an indication of the energy importance to residents in the county, and Energy Per Square Mile gives a measure of energy intensiveness in the county. In each of the three cases the Bay Area and the Los Angeles area were major markets, as would be expected. The breakdown of energy purchased by counties is displayed in Appendix A, for the six major process heat industries. 


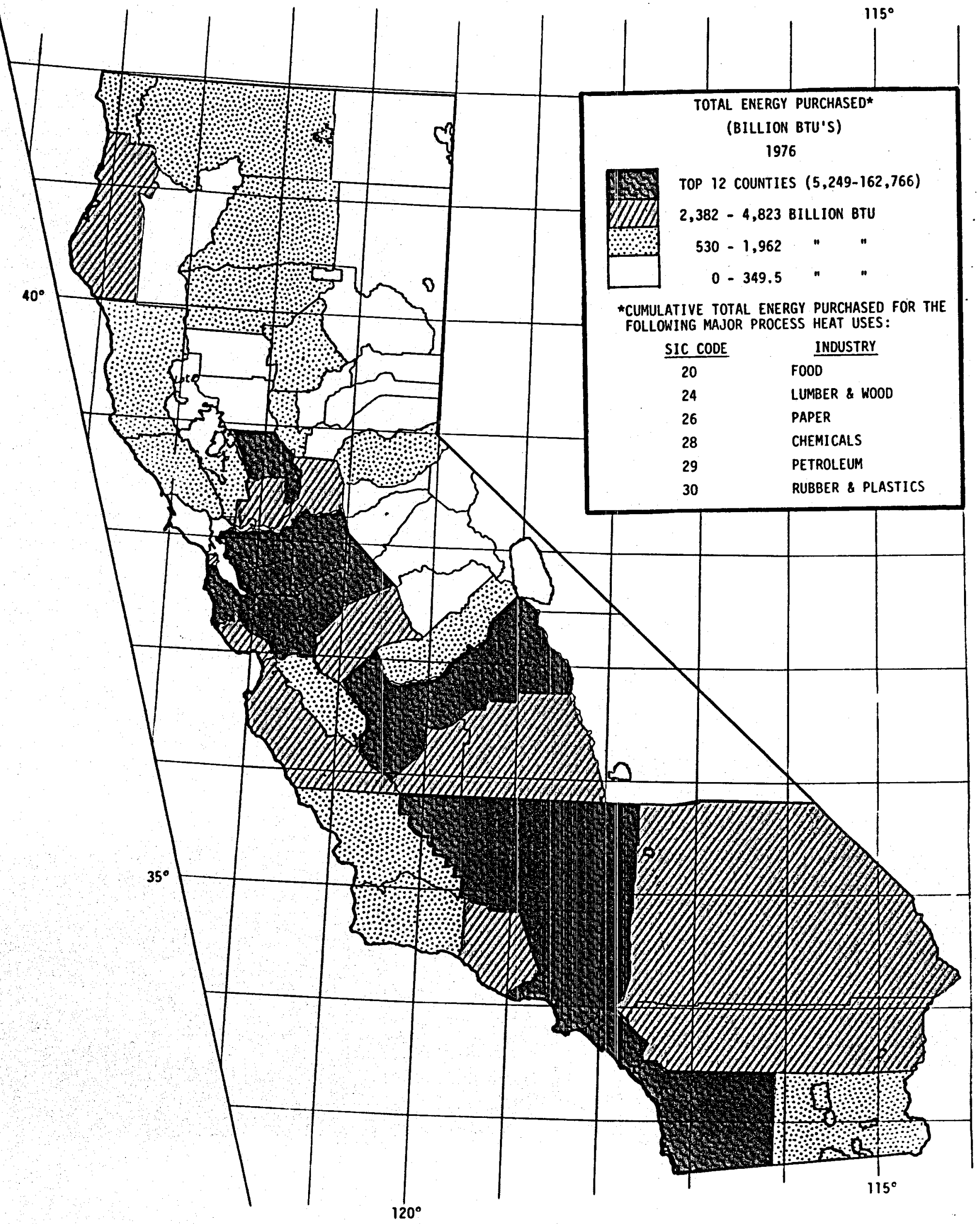

Figure 7. Total Energy Purchased for Selected Industries, 1976 (Billion BTU's) 


When total energy use is the criterion, Southern Californla appears to be the more important market. When energy use percapita is the criterion, the counties in the Northern portion of the state are the best markets, due to the importance of the lumber and paper industries. Energy use per square mile is probably the best market indicator. It indicates strong markets along the coast.

Table 11 indicates the top twelve counties under each of the three criteria. Five counties rank in the top twelve in each case using these three criteria: Contra Costa (which would appear by far the best market), Los Angeles, Stanislaus, San Joaquin, and Yolo County. These counties have high energy usage. Some of the lesser developed counties may also hold promise for development. Most of the interest in geothermal to date in California has been with electric power production; direct heat applications have not been demonstrated. Federal involvement in direct heat applications could accelerate development of resources much the same as has occurred in Oregon. Figure 10 displays the profection of BTU's in operation with and without federal assistance. 
Market Indicators* Top 12 Counties (Billion BTUs)

In California

\begin{tabular}{lll} 
& Energy Use Per & Energy Use Per \\
Total Energy Use & Capita (Milion & Square Mile \\
(Billion BTU's) & BTU Per Capita) & (Billion BTU/sq mi) \\
\hline
\end{tabular}

1. Los Angeles $(162,766)$

2. Contra Costa $(47,596)$

3. Orange $(20,023)$

4. Alameda $(19,857)$

5. Santa Clara $(12,033)$

6. $\operatorname{Kern}(8,601)$

7. Stanislaus $(7,915)$

8. San Joaquin $(6,757)$

S. San Mateo $(6,632)$

10. San Diego $(6,463)$

11. Fresno $(6,285)$

12. Yolo $(5,249)$
Contra Costa (79.6) Contra Costa (59.6)

Kings (54.1)

Los Angeles (39.9)

Yolo (50.1)

Alameda (24.0)

Tehama (45.7)

Santa Clara (9.1)

Del Norte (37.5) Solano (5.5)

Stanislaus (34.3) Santa Cruz (5.4)

San Benito (29.8)

San Francisco (5.3)

Humboldt (28.6)

Stanislaus (5.2)

Solano $(25.0)$

Yolo $(5.0)$

Kern (24.3)

San Joaquin (4.7)

Los Angeles (23.2) Sacramento (4.0)

San Joaquin (22.4) Kings (2.6)

*For SIC Codes $20,24,26,28,29,30$ 


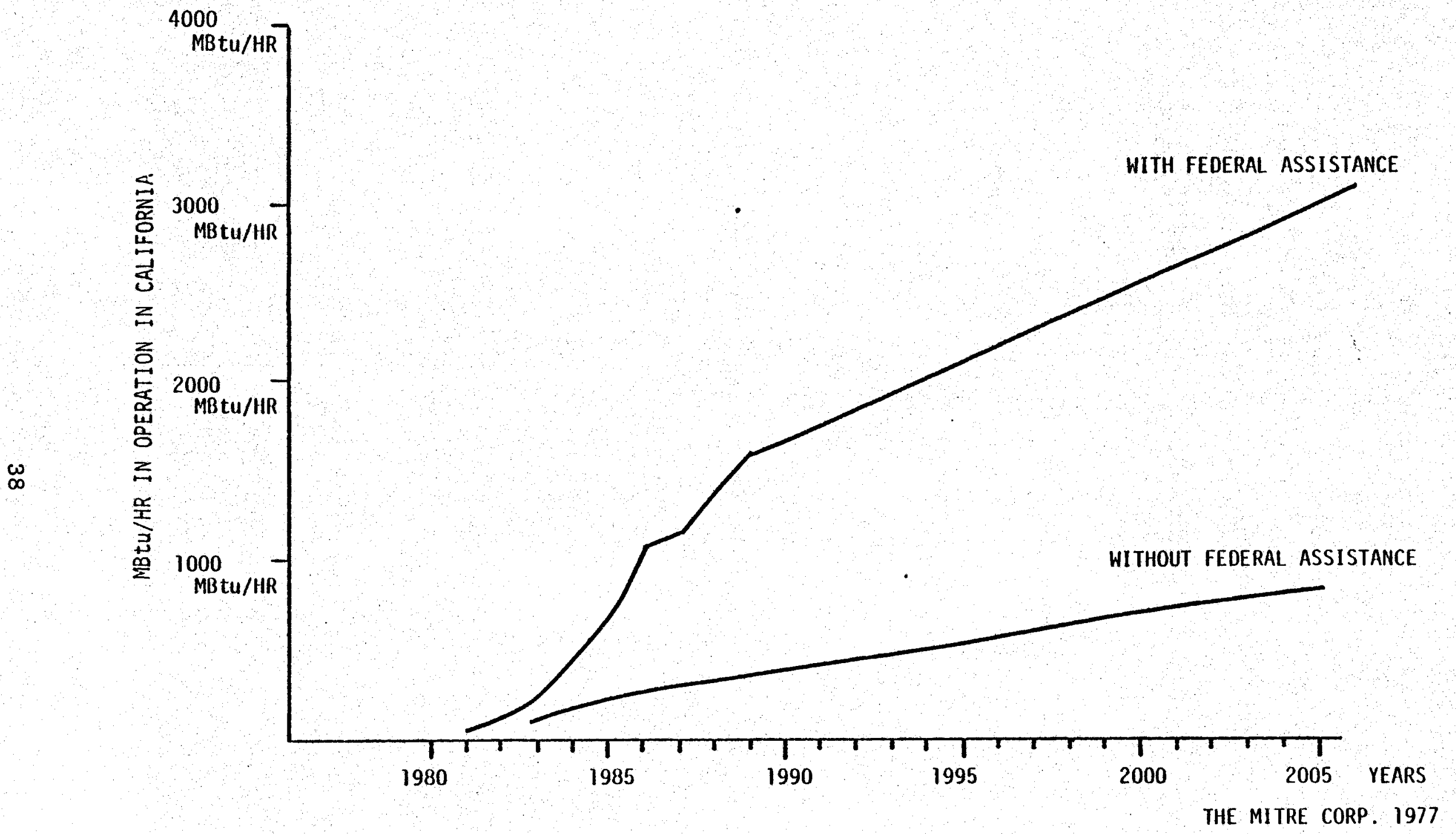

Figure 10. Projection of Geothermal MBtu/HR in Operation for Direct Heat Applications in California 
Sugar refineries, pineapple canneries, and various processing plants are among the process heat users in Hawail. Table 13 indicates the process heat requirements, cost per million BTU and energy as a percent of product cost for some of the major process heat using industries in Hawail. Competitive energy costs in Hawail range from $\$ 1.56$ to $\$ 4.93$ per milition BTU's.

For comparison, an industrial park at Keaau, near the Puna well on Hawail, will be exemplified. An estimate of the cost of drilling a well ( $\$ 1.5$ million) and building an 18-mile pipeline from Puna to Keaau ( $\$ 3$ million) delivering $4.1 \times 10^{11}$ BTU per year at an operating cost of $\$ 400,000 /$ year was made. Given a $12 \%$ return on investment and $75 \%$ debt at $9 \%$ interest rate the "GEYSER" Economic Feasibility Model determined that the cost of delivered BTU's would be $\$ 2.03$ per million BTU, indicating that geothermal energy would be reasonably competitive and, perhaps, very competitive (depending upon the character of these resources and proximity of the resource to the application relative to other fuels).

Totaling the process heat requirements for the industries in Table 13 , we find a total potential of $9.532 \times 10^{13}$ BTU's per year or 0.095 quads, a possible substantial energy displacement.

Figure 11 displays the projection of BTU's in operation with and without federal assistance for the State of Hawail.

Looking at the six major process heat users that were highlighted for California, a breakdown of energy usage by county was prepared by using Census of Manufacture data and County Business Patterns for Hawaii displayed in Table 12. 
Energy Purchased by Six Major Process Heat Using Industries for the State of Hawali, by County 1976 (SIC Code trillion BTU's)

\begin{tabular}{|c|c|c|c|c|c|c|}
\hline County & $\begin{array}{l}\text { Food } \\
(20)\end{array}$ & $\begin{array}{l}\text { Lumber } \\
\& \text { Wood } \\
(24)\end{array}$ & $\begin{array}{l}\text { Paper } \\
(26)\end{array}$ & $\begin{array}{l}\text { Chem } \\
(28)\end{array}$ & $\begin{array}{l}\text { oil } \\
\text { Refining } \\
(29)\end{array}$ & $\begin{array}{l}\text { Rubber } \\
\& \text { Plastic } \\
(30)\end{array}$ \\
\hline Hawaii & 1.377 & - & $=$ & $=$ & 1.032 & - \\
\hline Honolulu & 3.666 & .174 & .240 & .469 & 2.913 & .501 \\
\hline Lauai & .495 & -- & -- & -- & -- & -- \\
\hline Maui & 1.186 & -- & - & -- & -- & - \\
\hline State Wide & 6.742 & .191 & .243 & .477 & 3.780 & .052 \\
\hline
\end{tabular}

The County of Honolulu accounts for the major share of industry in the Islands. At the present time the only geothermal well is on the Big Island of Hawail. Comparing Table 12 (1978) with Table 13 (1976), it can be seen that processed heat for the six categories has increased considerably. It should be noted that Table 12 records purchased fuels only and that captive energy supplies exist. Bagasse is burned in the sugar refining process and accounts for a considerable portion of fuel usage. 
Table 13. Hawail State Fixed Industries Process Heat Energy Consumption

\begin{tabular}{|c|c|c|c|c|c|c|}
\hline & TLATI NANE ISLND & TRE or & OF DARA & Coss $351 \times 10^{9}$ & $\$ /$ onsts $\times 10-6$ & $\begin{array}{l}202 x \% \text { or } \\
25000 \mathrm{cos} x\end{array}$ \\
\hline 4. & (3 Planes) OAYH & UnIIS & 2975 & 48,013 & 1.36 & $4 \pi$. \\
\hline & $\begin{array}{l}\text { CIRYRCA USA } \\
\text { BARBES TT. OAII }\end{array}$ & orl & 1977 & 4.985 & $w / A$ & $4.5-57$ \\
\hline & $\begin{array}{l}\text { YED } \\
\text { (2 Planes) YALT }\end{array}$ & IIIIIX & 1975 & 3,662 & 2.0 & $40 \%$ \\
\hline & 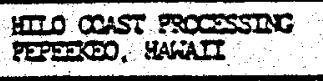 & STEAR & 1975 & 3,153 & $=$ & $*$ \\
\hline & 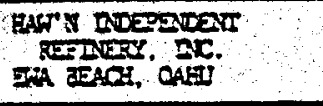 & Or & 1976 & 3,041 & 2.23 & $\mathbf{N} / \mathbf{A}$ \\
\hline 6. & 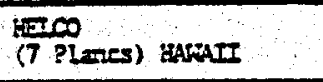 & जण IIS & 1975 & 2,341 & 1.34 & $26 \pi$ \\
\hline & 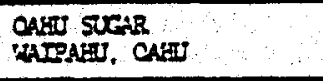 & SLCAR & 1973 & 2.423 & $\star \therefore$ & * \\
\hline 8 & 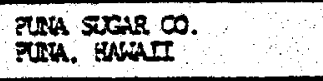 & SUEAR & 1975 & 2.333 & $*$ & $*$ \\
\hline & $\begin{array}{l}\text { HASE'N COML } \& \text { SOCAB } \\
\text { PLUEN, YAII }\end{array}$ & STCAR & 1975 & $\therefore \quad 2.320$ & $+\quad-$ & $*$ \\
\hline & $\begin{array}{l}\text { WAGPY COYL E STCAR } \\
\text { PAEA, YAII }\end{array}$ & $\operatorname{sen}$ & 9975 & 1.979 & $*$ & 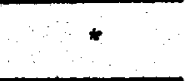 \\
\hline & 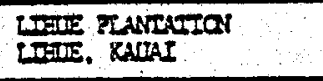 & $\operatorname{SeciR}$ & 1975 & 1.960 & $\star$ & $\star$ \\
\hline 12. & MLNUM setr o. & $\operatorname{sT} A 2$ & 1975 & 1,944 & $\star$ & $\pi$ \\
\hline 13. & 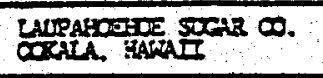 & STER & 1575 & 4.942 & $*$ & $*$ \\
\hline 14. & 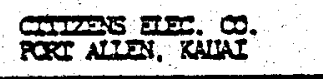 & Unters & 1975 & 1.780 & 2.2 & $35 \%$ \\
\hline L. & $\begin{array}{l}\text { ZA'U STEAR D. } \\
\text { PABALA. EARADI }\end{array}$ & $\sec 2$ & 1975 & 1.572 & $\star$ & 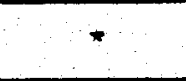 \\
\hline i6. & 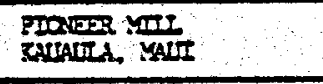 & $\operatorname{STAR}$ & 1973 & 2.300 & $\star$ & + \\
\hline & 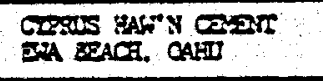 & caers. & 1976 & 1.393 & 2.9 & $50 \%$ \\
\hline & $\begin{array}{l}\text { STRODE STRAR } \infty . \\
\text { COA. SAULI }\end{array}$ & SUEAR & 1975 & 1.382 & $\star$ & - \\
\hline 19. & 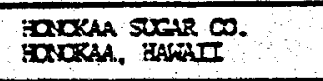 & $\operatorname{sun}$ & 2975 & 1,254 & 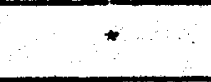 & 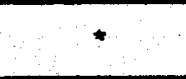 \\
\hline 20. & $\begin{array}{l}\text { TATSeR Cand } \\
\text { SAXARTI, CAEI }\end{array}$ & Cossir & 1976 : & 1.278 & 2.9 & $45 \%$ \\
\hline 2 & 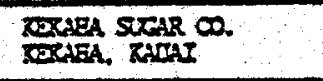 & STEAR & 1975 & 1.022 & + & 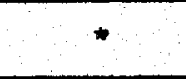 \\
\hline 22. & 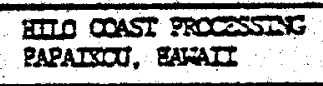 & STER: & 1975 & 956 & $\bullet$ & - \\
\hline & $\begin{array}{l}\text { OCOKEIS STRAR } \infty \\
\text { RALARANI, RACAI }\end{array}$ & STEAR: & 1975 & 906 . & $\star$ & $\star$ \\
\hline 24. & $\frac{\mathrm{ATIRS}}{\mathrm{MNI}}$ & stcas & 1975 & 498 & $\div$ & $\bullet$ \\
\hline & 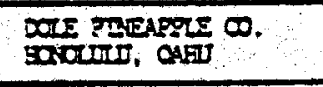 & CANEars & $19 n$ & 418 & 1.99 & $5 \%$ \\
\hline & $\begin{array}{l}\text { HVY FOWER RLANI } \\
\text { FEAR GARBOR, CAEI }\end{array}$ & SAVT & 1977 & 389 & 2.6 & $\mathrm{Y} / \mathrm{A}$ \\
\hline & 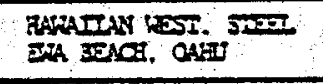 & ST्य & 1977 & 291 & 4.93 & $20-25 \%$ \\
\hline 39. & $\begin{array}{l}\text { Deros } \\
\text { CAIII }\end{array}$ & cas & 1976 & 234 & $\mathrm{~s} / \mathrm{A}$ & $i-3 \%$ \\
\hline & 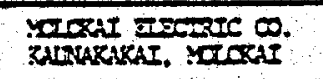 & जर्या: & 1975 & 232 & 2.58 & 437 \\
\hline
\end{tabular}

YOTE:

Dacz is dertued and/or is esefonted too rari ous daca souress and the liscing preseteed is a consse ordertag of isers. Aceuract of 307 san be teasonably assumed onty wichis indusefes. See Texe Eor discusion. Jugar gefiner7 jala on enerzy coses is somoll. caced by the buzing of bagasse, 1 jy-?zoducs of sugar processizg. tor the In jortsy of taeif ener37. Sae iaxe. 


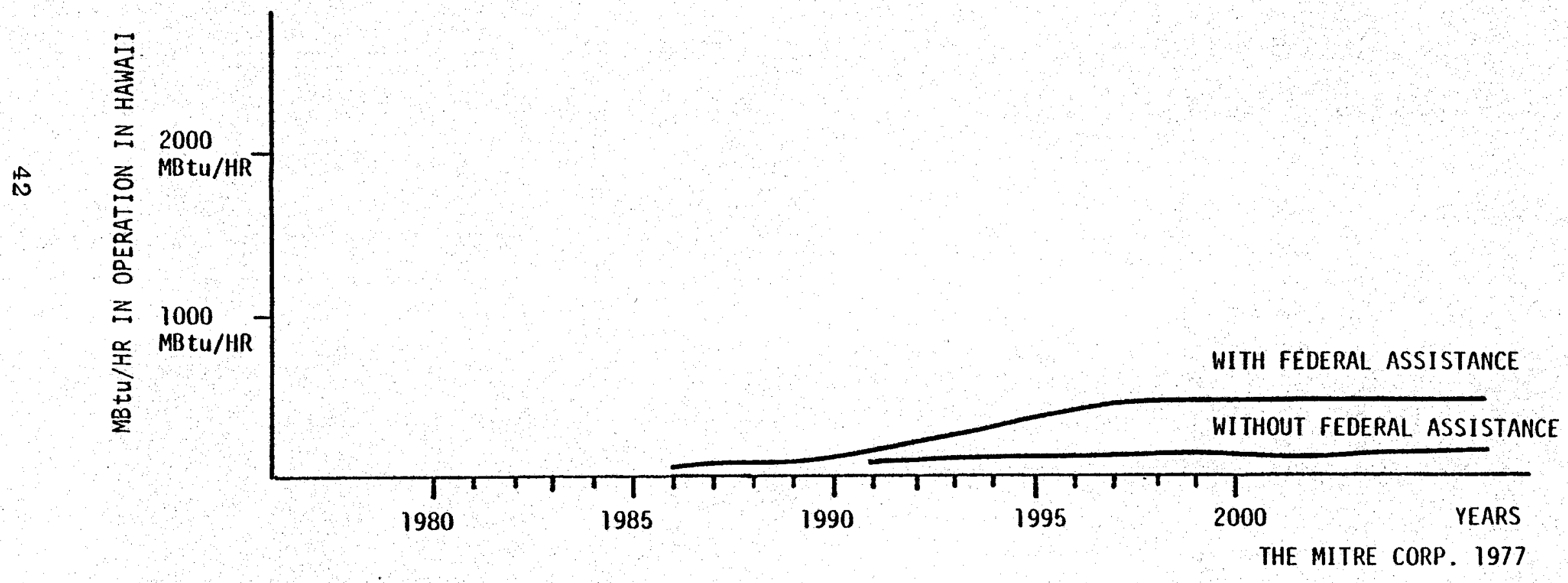

Figure 11. Projection of Geothermal MBtu/Hr. in Operation for Direct Heat Applications in Hawaii 


\section{MARKET PROSPECTS FOR MAJOR INDUSTRIAL DIRECT USE CANDIDATES (The National Market)}

\subsection{FOOD AND KINDRED PRODUCTS}

Food and beverage processors expect $7 \%$ growth in 1978 shipments. Energy, weather, government regulations, and consumer issues impact the food processing industry. The nation had an abundant supply of basic foodstuffs in late 1977 and the outlook for 1978 is bright.

Table 14 displays the percent increase in value of shipments from 1976 to 1977 and the projection from 1977 to 1978 for various processed foods, from the 1978 U.S. Industrial Outlook. Looking at these figures, one should assume a $6 \%$ inflation rate. In this light, many of the products appear to have actual reductions in production. Those industries which would appear to have special interest in geothermal process heat are poultry dressing plants, dairy products, canned goods, dried and dehydrated goods, frozen goods, and malt beverages, all of which have expected increased production of over $8 \%$ in current dollars.

The food processing industry has become increasingly concerned about shortages of various types of fuel. The canning industry has been motivated to achieve a $9.3 \%$ improvement in energy efflciency from 1972 to 1976. The frozen food industry has a target of an $11 \%$ reduction in energy consumption per unit of production by 1980. The increase in the concern over energy costs and availability provides an incentive for the food industry to consider geothermal energy. 
Table 14. Food and Kindred Products: Trends and Projections 1975-78(1) (Value of Shipments in Millions of Current Dollars Except as Noted)

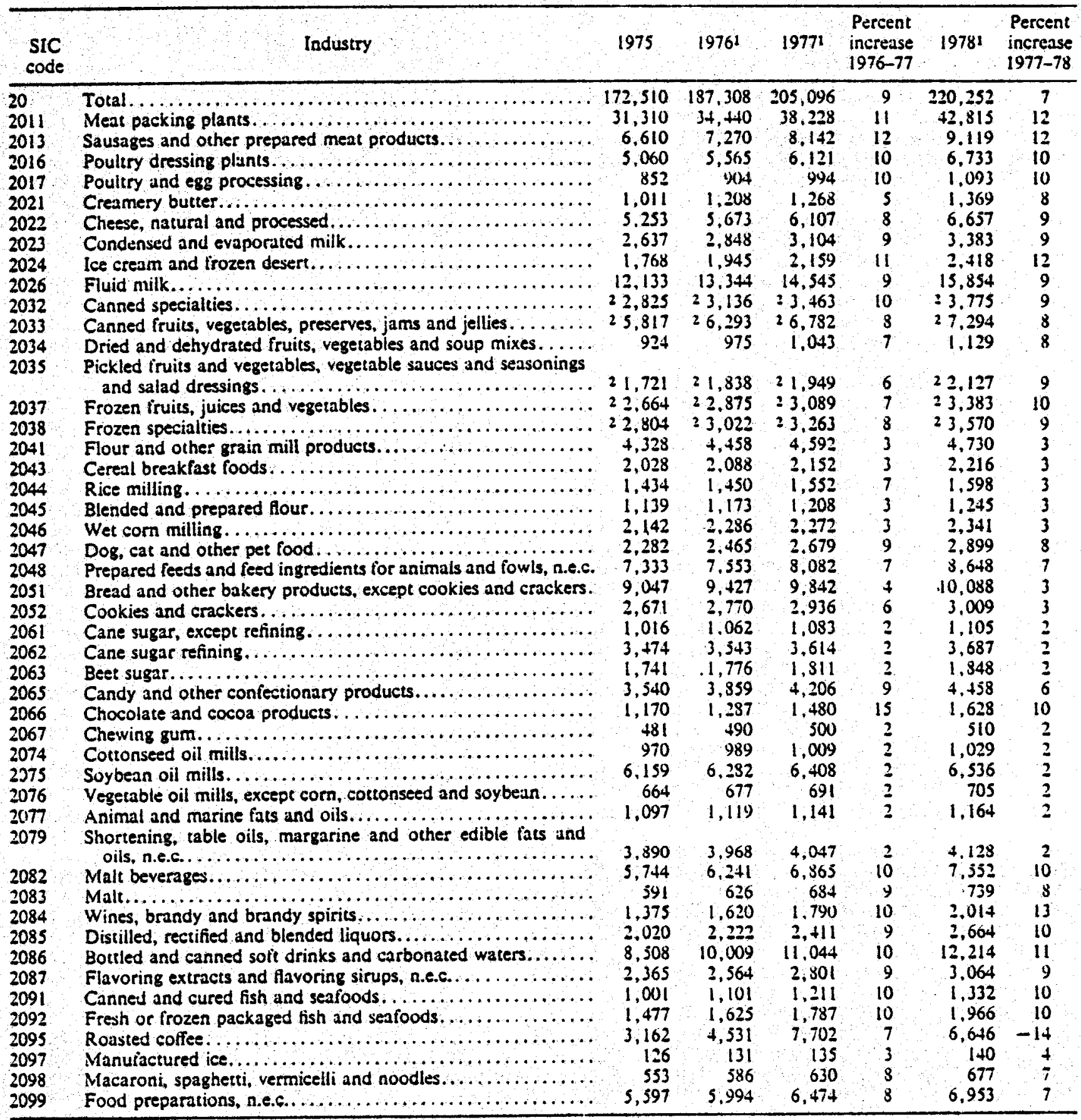

IEstimated by Bureau of Domestic Commerte (BDC).

i Establishments in this industry reported value oi production, not value of

shipments. n.c.c. = Nol slsewhere classilied. 
In 1978, lumber and plywood production is expected to reach near-capacity levels. Lumber exports should rise, softwood plywood exports should drop. Lumber prices are expected to peak with increased employment and efficiency. Wood residues are Increasingly being used as an energy source. Some companies are producing enough energy to meet their own needs and sell it to other industrial firms as well. (Presently, a hybrid system power plant using wood residues and geothermal energy as fuel sources is being considered very seriously near susanville, California.) A major benefit of using geothermal energy in lumber production would be to free the wood residue for power production. A company in California already sells surplus electricity under a long-term contract to a nearby city. (Lumber output is influenced largely by trends in construction, which is presently at a very high level in California).

The paper and paperboard industry is the fourth largest manufacturing industry in the United States and has the fifth fastest rate of real growth. Virtually all of the northern counties in California are lumber producing, providing raw materials to the pulp and paper industry. Product shipments for rulp, paper and board, and converted products are expected to rise 11\% from 1977 to 1978 . Paper and board production in 1978 is expected to be $5 \%$ over 1977 .

Table 15 displays pulp production, annual capacity, and the operating ratio (production as a percent of capacity) for the years 1968 through 1978 . 
Table 15. Wood Pulp Production: Actual 1963-76; Projections 1977-78 (000 Short Tons)

\begin{tabular}{|c|c|c|c|c|c|c|}
\hline Year & $\begin{array}{l}\text { Pulp } \\
\text { production- } \\
\text { all grades }\end{array}$ & $\begin{array}{c}\text { Annual } \\
\text { capacity1 }\end{array}$ & $\begin{array}{l}\text { Operating ratio } \\
\text { (production } \\
\text { as a percent } \\
\text { of capacity) }\end{array}$ & Exports & Imports & $\begin{array}{c}\text { Apparent } \\
\text { new supply }\end{array}$ \\
\hline 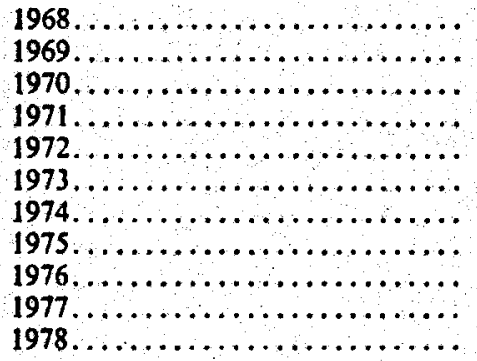 & $\begin{array}{l}40,892 \\
42,813 \\
43,546 \\
43,903 \\
46,767 \\
48,327 \\
48,417 \\
43,084 \\
48,804 \\
50,300 \\
52,600\end{array}$ & $\begin{array}{l}43,120 \\
44,834 \\
45,863 \\
47,107 \\
48,731 \\
50,674 \\
51,295 \\
51,927 \\
53,057 \\
54,678 \\
55,933\end{array}$ & $\begin{array}{l}94.8 \\
95.5 \\
94.9 \\
93.2 \\
96.0 \\
95.4 \\
94.4 \\
82.9 \\
92.0 \\
92.0 \\
94.0\end{array}$ & $\begin{array}{l}1,915 \\
2,103 \\
3,095 \\
2,175 \\
2,237 \\
2,344 \\
2,806 \\
2,565 \\
2,587 \\
2,760 \\
2,800\end{array}$ & $\begin{array}{l}3,532 \\
4,040 \\
3,518 \\
3,515 \\
3,773 \\
3,993 \\
4,123 \\
3,078 \\
3,727 \\
3,940 \\
4,000\end{array}$ & $\begin{array}{l}42,509 \\
44,750 \\
43,969 \\
45,243 \\
48,303 \\
49,976 \\
49,734 \\
43,597 \\
49,940 \\
51,480 \\
53,800\end{array}$ \\
\hline
\end{tabular}

API Capacity Survey: 1975-1978 revesions.

Source: Bureau of the Census, American Paper Institute, and BDC.

The new capacity for wood pulp production comes substantially from mill modernization, the addition of on-site incremental capacity, and replacement of older pulping technology with newer processes. New technology developments in the area of thermomechanical pulping (TMP) are presently being adopted. This process requires greater amounts of energy and geothermal energy may be able to help serve this need.

Shipments of paper and board are expected to grow at a rate of $4.1 \%$ per year until 1982. The U.S. paper industry was expected to spend approximately $\$ 3.5$ bilion for new plants and equipment in 1977, a $2.4 \%$ increase over 1976 . Approximately $55 \%$ of the capital investment goes into paper mills. This high rate of capital development should provide opportunities for applications of geothermal energy.

\subsection{CHEMICALS AND ALLIED PRODUCTS}

The chemical industry utilizes the highest amount of energy per unit of output of any industrial sector. Energy is a most important issue, as the industry is dependent upon petroleum and natural gas feedstocks. Energy is important both as a fuel and as a feedstock. Energy consumption in the chemical industry 
in 1976 amounted to over 3 quads. Table 16 displays the composition of energy usage for the the industry.

Table 16. Energy Consumption of the Chemical Industry, 1976 January-December

\begin{tabular}{|c|c|}
\hline Energy Type & Consumption $(1012 \mathrm{BTU})$ \\
\hline 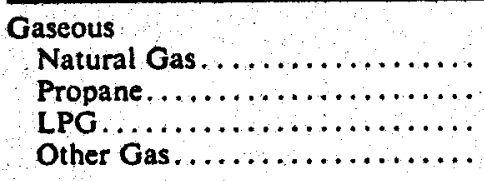 & $\begin{array}{r}1,307.1 \\
13.1 \\
11.3 \\
264.8\end{array}$ \\
\hline 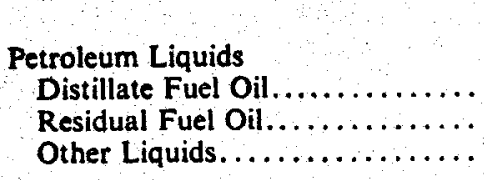 & $\begin{array}{r}1.596 .3 \\
54.3 \\
191.3 \\
45.2\end{array}$ \\
\hline 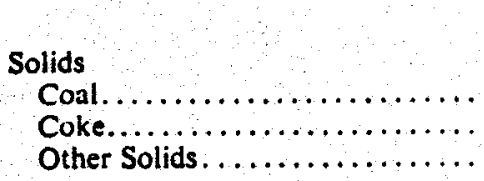 & $\begin{array}{r}290.8 \\
279.2 \\
6.5 \\
11.9\end{array}$ \\
\hline & 297.6 \\
\hline Purchased Steam. & 144.4 \\
\hline Purchased Electric Power.......... & 769.1 \\
\hline Total.................... & $3,098.2$ \\
\hline
\end{tabular}

The chemical industry is critically dependent upon a stable energy supply, and therefore, plans for energy supplies to a higher degree than other industries, and is very interested in alternative energy supplies. Dow Chemical has been active in securing resources in the Gulf Coast region. Successful demonstration of direct heat application in California could have a formidable impact upon the chemical industry's interest in geothermal resources in California. Table 17 below displays the energy conversion processes used in the chemical industry. Process heat accounts for almost $60 \%$ of the energy usage. 
Table 17. Energy Consumption by the Chemical Industry Utilization by Conversion Process

\begin{tabular}{|c|c|}
\hline Process & $\begin{array}{c}\text { Energy Usage } \\
\text { (1012 BTU) }\end{array}$ \\
\hline 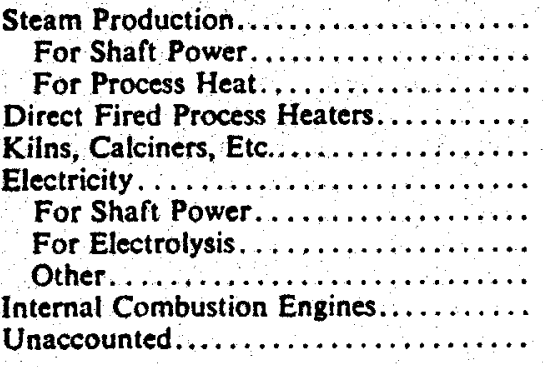 & $\begin{array}{r}1,800 \\
(400) \\
(1,400) \\
450 \\
250 \\
380 \\
(250) \\
(100) \\
(30) \\
150 \\
70\end{array}$ \\
\hline Total .............. & 3,100 \\
\hline
\end{tabular}

Table 18 indicates the growth rates for several of the chemicals and allied products. Plastics Materials \& Resins is the fastest growing sector, with a $14 \%$ growth rate projected for 1978. Chlor-Alkali, Inorganic Pigments, Drugs and Pharmaceuticals, Soaps \& Detergents, Paints \& Allied Products, Industrial Organic Chemicals, and Pesticides also has high expected growth rates, exceeding $9 \%$ per year. Assuming a $6 \%$ inflation rate, the real growth for these industries ranges from $3 \%$ to $8 \%$ for the year.

Table 18. Chemicals and Allied Products: Projections $1976-78^{(1)}$

\begin{tabular}{|c|c|c|c|c|c|c|c|}
\hline $\begin{array}{l}\text { SIC } \\
\text { Code }\end{array}$ & Industry & 19761 & $\begin{array}{c}\text { Percent } \\
\text { change } \\
1975-76\end{array}$ & 19771 & $\begin{array}{l}\text { Percent } \\
\text { change } \\
1976-77\end{array}$ & 19781 & $\begin{array}{c}\text { Percent } \\
\text { change } \\
1977-78\end{array}$ \\
\hline $\begin{array}{l}2812 \\
2813 \\
2816 \\
2819 \\
2821 \\
2822 \\
283 \\
2841 \\
2844 \\
2851 \\
2865 \\
2869 \\
2873 \\
2874 \\
2879\end{array}$ & 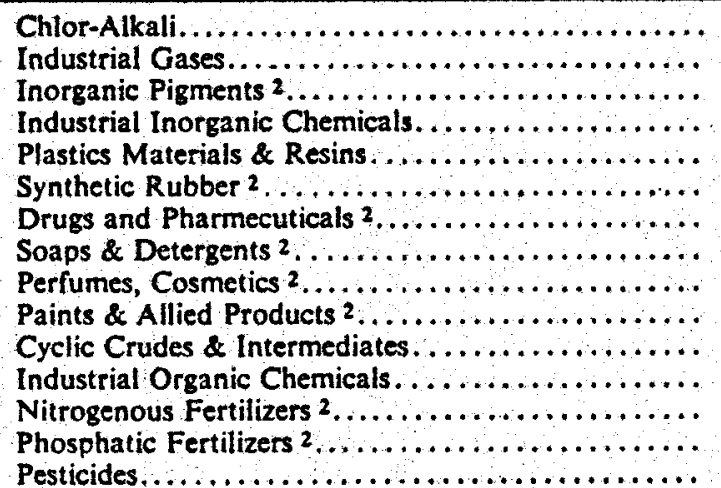 & $\begin{array}{r}1,800 \\
1,210 \\
1,150 \\
7,127 \\
8,255 \\
1,845 \\
12,260 \\
5,285 \\
5,505 \\
5,950 \\
4,420 \\
19,150 \\
2,100 \\
3,000 \\
2,635\end{array}$ & $\begin{array}{r}11 \\
10 \\
18 \\
16 \\
15 \\
25 \\
9 \\
12 \\
9 \\
16 \\
16 \\
13 \\
-13 \\
9 \\
15\end{array}$ & $\begin{array}{r}1,900 \\
1,308 \\
1,200 \\
7,646 \\
9,600 \\
2,100 \\
13,350 \\
5,920 \\
5,940 \\
6,075 \\
4,690 \\
21,800 \\
2,175 \\
3,150 \\
2,900\end{array}$ & $\begin{array}{l}6 \\
8 \\
4 \\
7 \\
9 \\
14 \\
9 \\
12 \\
8 \\
2 \\
6 \\
14 \\
4 \\
5 \\
10\end{array}$ & $\begin{array}{r}2,100 \\
2,300 \\
1,310 \\
7,953 \\
10,300 \\
2,250 \\
14,550 \\
6,570 \\
6,420 \\
6,655 \\
5,150 \\
24,000 \\
2,250 \\
3,275 \\
3,200\end{array}$ & $\begin{array}{r}11 \\
7.4 \\
9 \\
4 \\
14 \\
7 \\
9 \\
11 \\
8 \\
9 \\
10 \\
10 \\
3 \\
4 \\
10\end{array}$ \\
\hline
\end{tabular}

1 Estimated by Bureau of Domestic Commerce (BDC).

1 These industries are part of Chemicals and Allied Products 
Natural gas curtailments for 1978 (nationwide) are expected to be over 20\%. Because the natural gas is required as a feedstock, alternative fuels must be used as replacements in the future. Geothermal energy $w 11$ be an ldeal substitute, once its reliability is established. The industry recognizes the higher use of petroleum and natural gas as feedstocks and the need to curb the use of these valuable resources as an energy source.

6.4 RUBBER AND MISCELLANEOUS PLASTICS

Table 19 below indicates the growth rates for the seven categories under Rubber and Miscellaneous Plastics. Assuming a $6 \%$ inflation rate, synthetic rubber, tires, and inner tubes have slight increases in production. Rubber and plastics footwear and reclaimed rubber have effective decreases in production. Hose and belting, rubber, and miscellaneous products have net increases in production, ranging from 3 to $6 \%$.

Table 19. Rubber and Plastics: Trends and Projections 1975-78 (Value of Shipments in Milions of Current Dollars)

\begin{tabular}{|c|c|c|c|c|c|c|c|c|}
\hline $\begin{array}{l}\text { SIC } \\
\text { Code }\end{array}$ & Industry & 1975 & 1976 & $\begin{array}{l}\text { Percent } \\
\text { change } \\
1975-76\end{array}$ & 1977 & $\begin{array}{l}\text { Percent } \\
\text { change } \\
1976-77\end{array}$ & 1978 & $\begin{array}{c}\text { Percent } \\
\text { change } \\
1977-78\end{array}$ \\
\hline \multirow[t]{2}{*}{$\begin{array}{l}2822 \\
3011 \\
3021 \\
3031 \\
3041 \\
3069 \\
3079\end{array}$} & 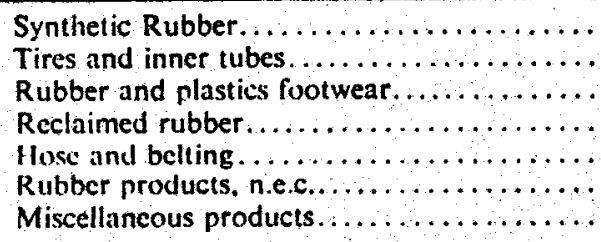 & $\begin{array}{r}1,481 \\
7,143 \\
566 \\
28 \\
1,235 \\
3,412 \\
14,932\end{array}$ & $\begin{array}{r}1,845 \\
8,450 \\
570 \\
20 \\
1,375 \\
3,900 \\
18,700\end{array}$ & $\begin{array}{r}25 \\
18 \\
1 \\
-29 \\
11 \\
14 \\
25\end{array}$ & $\begin{array}{r}2,100 \\
10,200 \\
575 \\
20 \\
1,500 \\
4,200 \\
20,500\end{array}$ & $\begin{array}{r}14 \\
21 \\
1 \\
0 \\
9 \\
8 \\
10\end{array}$ & $\begin{array}{r}2,250 \\
11,000 \\
575 \\
20 \\
1,650 \\
4,600 \\
23,000\end{array}$ & $\begin{array}{r}7 \\
8 \\
0 \\
0 \\
10 \\
10 \\
12\end{array}$ \\
\hline & Totals $\ldots \ldots \ldots \ldots \ldots \ldots$ & 28,797 & 34,860 & & 39,095 & & 43,095 & \\
\hline
\end{tabular}

Estimated by Bureau of Domestic Commerce (BDC).

n.e.c. - Not elsewhere classified.

Capital expenditures $1 n$ these industries in 1978 can be expected to be approximately $\$ 1.5$ billion nationally.

$6.5 \quad$ PETROLEUM REFINING

Table 20 displays the source of crude oil and the composition of petroleum product outputs for the state of California. Total energy consumption in California in 1976-77 
(October through september) was 6.317 quads, of this amount 4.044 quads were supplied by petroleum products. The petroleum product output for California in $1976-77$ was $736,802,000$ barrels of various products. Assuming an average of 5.5 million BTU's per barrel, this amounts to 4.052 quads, indicating that California can effectively produce and refine enough petroleum to meet its own needs. About $84 \%$ of this energy is consumed in California. Out-of-state sales in $1976-77$ were $115,367,000$ barrels; imports were $52,369,000$, for a net export of $8.5 \%$ of the refinery output.

The market for petroleum products fluctuates depending upon the amount of fuel in storage and expected prices of foreign crude, but over the long run the market is fairly stable. The critical nature of petroleum products to the national economy ensures that there $w 111$ be $a$ market for the refined products. There is at the present time a shortage of oil refineries because of siting difficulties due to environmental controls.

In 1976-77, California's feedstocks were heavily dependent upon foreign imports, about $44 \%$ of the crude coming from Arab countries, Indonesia, and Venezuela. As mentioned earlier in this paper, Foreign imports were reduced to $22 \%$ for the months of August, 1978. 
Table 20. California Refineries

\begin{tabular}{|c|c|c|c|c|c|c|c|c|}
\hline \multirow{2}{*}{ RlGit or noover } & \multicolumn{4}{|l|}{ QuAR } & \multicolumn{4}{|l|}{ Ful $r$} \\
\hline & & & ge & & \multicolumn{4}{|c|}{ Thousane lachels } \\
\hline \multirow{3}{*}{ 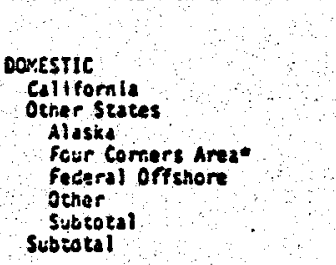 } & \multicolumn{8}{|c|}{ CRUDE OLL RECEIPTS } \\
\hline & 23187. & 75375 & 2183 & 3.0 & 300319 & 310030 & 9711 & 3.3 \\
\hline & $\begin{array}{l}9364 \\
410 \\
745 \\
\frac{67}{10506} \\
83793\end{array}$ & $\begin{array}{r}22946 \\
249 \\
644 \\
200 \\
\frac{3659}{99234}\end{array}$ & $\begin{array}{r}13582 \\
-\quad 161 \\
-\quad 101 \\
\quad 57 \\
\frac{1353}{1544}\end{array}$ & $\begin{array}{r}145.0 \\
-\quad 39.3 \\
13.6 \\
77.0 \\
125.0 \\
18.4\end{array}$ & $\begin{array}{r}48573 \\
4509 \\
3105 \\
48271 \\
\frac{53124}{353443}\end{array}$ & $\begin{array}{r}13769 \\
995 \\
2528 \\
\frac{186}{3638} \\
\frac{356350}{357603}\end{array}$ & $\begin{array}{r}3096 \\
-3514 \\
117 \\
-\frac{4551}{5196} \\
1225\end{array}$ & $\begin{array}{r}7.6 \\
-\quad 7.9 \\
-96.4 \\
-96.3 \\
01.2\end{array}$ \\
\hline \multirow{2}{*}{ 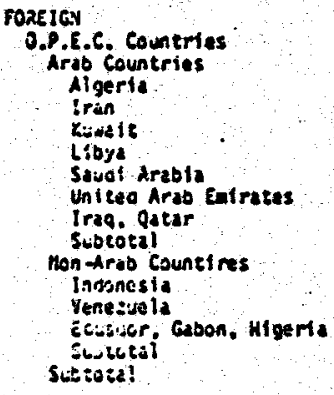 } & $\begin{array}{r}4801 \\
325 \\
1452 \\
14543 \\
1911 \\
2068 \\
25151\end{array}$ & $\begin{array}{r}0 \\
3649 \\
973 \\
24670 \\
1592 \\
5809 \\
15092\end{array}$ & 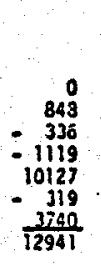 & $\begin{array}{r}0 \\
17.7 \\
-100.0 \\
-75.0 \\
69.6 \\
16.7 \\
180.9 \\
51.5\end{array}$ & $\begin{array}{r}1307 \\
19743 \\
0 \\
2313 \\
51227 \\
0530 \\
10097 \\
93327\end{array}$ & $\begin{array}{r}26793 \\
0 \\
877 \\
87791 \\
7673 \\
18998 \\
142098\end{array}$ & 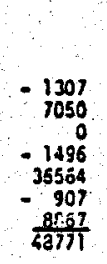 & $\begin{array}{r}100.0 \\
35.7 \\
-\quad 63.0 \\
717.4 \\
-10.6 \\
87.8 \\
52.3\end{array}$ \\
\hline & 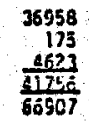 & $\begin{array}{r}29155 \\
654 \\
\frac{5900}{35514} \\
73601\end{array}$ & $\begin{array}{r}-7803 \\
279 \\
-\frac{1277}{6547} \\
6694\end{array}$ & $\begin{array}{r}21.1 \\
27.6 \\
-\quad 15.0 \\
10.0\end{array}$ & $\begin{array}{r}113989 \\
3195 \\
\frac{953}{125159} \\
215459\end{array}$ & $\begin{array}{r}142936 \\
1662 \\
\frac{10.927}{1.9625} \\
305723\end{array}$ & $\begin{array}{r}28941 \\
-1453 \\
\frac{2949}{37593} \\
\frac{30204}{30204}\end{array}$ & $\begin{array}{r}25.4 \\
-66.0 \\
110.3 \\
29.7 \\
39.3\end{array}$ \\
\hline $\begin{array}{l}\text { Non-u.P.E.C. Countrio } \\
\text { Latin sierfea } \\
\text { All ocher } \\
\text { Subtotal } \\
\text { Sub total }\end{array}$ & $\frac{3763}{\frac{2234}{5977}} \frac{5}{726 j 4}$ & $\begin{array}{l}1630 \\
\frac{8065}{96 \% 5} \\
\frac{8,527 \%}{5325}\end{array}$ & $\begin{array}{r}-2133 \\
\frac{5851}{3718} \\
\frac{10412}{104}\end{array}$ & $\begin{array}{r}56.2 \\
264.3 \\
62.2 \\
14.3\end{array}$ & $\frac{10811}{\frac{7137}{17948}}$ & $\begin{array}{r}\frac{147}{21402} \\
\frac{24102}{3259} \\
333976\end{array}$ & $\frac{-2654}{\frac{16255}{6301}}$ & $\begin{array}{r}24.6 \\
237.7 \\
79.7 \\
42.4\end{array}$ \\
\hline TETAL: & 156677 & $\longdiv { 1 8 2 5 3 0 }$ & 25853 & 16.5 & $590 \_50$ & 895640 & 104790 & 17.7 \\
\hline \multirow{3}{*}{ 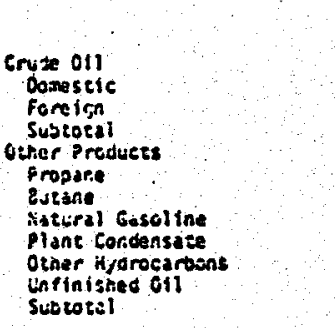 } & \multicolumn{8}{|c|}{ FEEOSTOCK IMOUT } \\
\hline & $\begin{array}{l}84775 \\
\frac{71517}{156292}\end{array}$ & $\begin{array}{r}96312 \\
84178 \\
\frac{840690}{18060}\end{array}$ & $\begin{array}{l}11537 \\
12461 \\
\frac{24398}{4438}\end{array}$ & $\begin{array}{l}\begin{array}{l}13.6 \\
18.0 \\
15.6\end{array}\end{array}$ & $\begin{array}{l}346678 \\
2,7928 \\
574006\end{array}$ & $\frac{356151}{\frac{320^{2} * 3}{679799}}$ & $\begin{array}{l}10073 \\
\frac{95720}{155753}\end{array}$ & $\begin{array}{r}2.9 \\
42.0 \\
18.9\end{array}$ \\
\hline & $\begin{array}{r}651 \\
920 \\
1113 \\
11994 \\
13915\end{array}$ & $\begin{array}{r}829 \\
1046 \\
3 \\
1079 \\
8615 \\
11570\end{array}$ & $\begin{array}{r}178 \\
126 \\
0 \\
-\quad 34 \\
-2475 \\
2209\end{array}$ & $\begin{array}{r}27.3 \\
13.1 \\
0 \\
-\quad 3.1 \\
=\quad 22.3 \\
-\quad 16.0\end{array}$ & $\begin{array}{r}24 \\
2955 \\
4561 \\
184 \\
4260 \\
52574 \\
64313\end{array}$ & $\begin{array}{r}3611 \\
3345 \\
0 \\
4730 \\
44652 \\
522+16\end{array}$ & $\begin{array}{r}-\quad 16 \\
-\quad 556 \\
\quad 536 \\
134 \\
\quad 530 \\
-\quad 7922 \\
472\end{array}$ & $\begin{array}{r}\quad 66.7 \\
22.2 \\
-\quad 12.2 \\
100.0 \\
12.5 \\
-15.1 \\
-11.6\end{array}$ \\
\hline TOTKL. & 17007 & 192260 & $\overline{22189}$ & 13.0 & $\overline{638324}$ & $\overline{736045}$ & $\overline{98321}$ & 15.4 \\
\hline \multirow{6}{*}{ 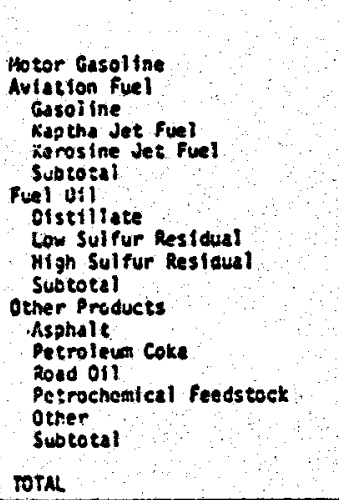 } & \multicolumn{8}{|c|}{ PETROLEUN PROOLCT OUTPUT } \\
\hline & 72270 & 80835 & 8565 & 11.9 & 271868 & 296687 & 26819 & 9.9 \\
\hline & $\begin{array}{r}836 \\
3205 \\
1 \frac{1429}{6230}\end{array}$ & $\begin{array}{r}1030 \\
3416 \\
\frac{16780}{21226}\end{array}$ & $\begin{array}{r}194 \\
211 \\
\frac{2591}{2996}\end{array}$ & $\begin{array}{l}23.2 \\
6.5 \\
18.3 \\
16.4\end{array}$ & $\begin{array}{r}2980 \\
13013 \\
53532 \\
69625\end{array}$ & $\begin{array}{r}3052 \\
16116 \\
60326 \\
\frac{77504}{750}\end{array}$ & $\begin{array}{r}72 \\
1103 \\
\frac{6704}{7019}\end{array}$ & $\begin{array}{l}2.4 \\
8.5 \\
12.5 \\
11.3\end{array}$ \\
\hline & $\begin{array}{l}19172 \\
77669 \\
15978 \\
52819\end{array}$ & $\begin{array}{l}21010 \\
23164 \\
12785 \\
61959\end{array}$ & $\begin{array}{l}1838 \\
5495 \\
1807 \\
9140\end{array}$ & $\begin{array}{r}9.6 \\
31.1 \\
11.3 \\
17.3\end{array}$ & $\begin{array}{l}69448 \\
61175 \\
66774 \\
197327\end{array}$ & $\begin{array}{l}83295 \\
94927 \\
71495 \\
845 E 57\end{array}$ & $\begin{array}{r}33247 \\
33722 \\
4711 \\
52340\end{array}$ & $\begin{array}{l}19.9 \\
55.3 \\
7.1 \\
26.5\end{array}$ \\
\hline & $\begin{array}{r}1382 \\
5498 \\
155 \\
1631 \\
13592 \\
\frac{135058}{5505}\end{array}$ & $\begin{array}{l}5477 \\
6630 \\
164 \\
1699 \\
16527 \\
30797\end{array}$ & $\begin{array}{r}1095 \\
1132 \\
208 \\
\frac{2635}{5739}\end{array}$ & $\begin{array}{l}25.0 \\
20.6 \\
5.8 \\
18.7 \\
23.8 \\
22.9\end{array}$ & $\begin{array}{r}15405 \\
22405 \\
580 \\
6354 \\
53012 \\
97757\end{array}$ & 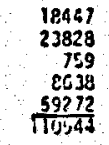 & $\begin{array}{l}3041 \\
1423 \\
173 \\
2264 \\
5253 \\
1316\end{array}$ & $\begin{array}{l}19.7 \\
6.4 \\
20.9 \\
35.9 \\
11.8 \\
13.5\end{array}$ \\
\hline & 8377 & $\overline{94817}$ & $\overline{26440}$ & 15.7 & $\overline{636577}$ & $\longdiv { 3 6 9 0 2 }$ & $\longdiv { 1 0 0 2 2 5 }$ & 15.7 \\
\hline \multicolumn{9}{|c|}{ COSTS: FEEDSTOCK IWPUT } \\
\hline CENOE OIL: & \multicolumn{3}{|l|}{976} & $\begin{array}{l}\text { Rercens } \\
\text { Change }\end{array}$ & $\frac{M 1}{1975-76}$ & $\frac{\text { Ion ooll }}{1076-i 1}$ & $\frac{1}{\text { Changs }}$ & $\begin{array}{l}\text { Percent } \\
\text { Cherge }\end{array}$ \\
\hline \multirow[t]{2}{*}{$\begin{array}{l}\text { potal cost } \\
\text { oosestic } \\
\text { forctign } \\
\text { Total }\end{array}$} & $\begin{array}{r}655.8 \\
\frac{911.8}{1607.6}\end{array}$ & $\frac{11558.5}{2014.1}$ & $\begin{array}{l}192.7 \\
\frac{213.8}{406.5}\end{array}$ & $\begin{array}{l}28.9 \\
22.7 \\
25.3\end{array}$ & $\begin{array}{l}2614.4 \\
\frac{3027.4}{5102.2}\end{array}$ & $\begin{array}{r}2917.8 \\
\frac{4470.7}{7305.7}\end{array}$ & $\begin{array}{r}303.4 \\
1393.1 \\
73.6 .5\end{array}$ & $\begin{array}{l}11.6 \\
44.8 \\
29.6\end{array}$ \\
\hline & 1976 & $\frac{1}{1977}$ & $\frac{\text { garrel }}{\text { Ichange }}$ & $\begin{array}{l}\text { Percent } \\
\text { Change }\end{array}$ & $1975-76$ & $\begin{array}{l}3 \text { per } 8 \\
\text { 1976.7 }\end{array}$ & rel & $\begin{array}{l}\text { Percent } \\
\text { Change }\end{array}$ \\
\hline $\begin{array}{l}\text { Unit cost } \\
\text { ocmestic } \\
\text { Poreign } \\
\text { Total }\end{array}$ & $\begin{array}{r}7.85 \\
13.17 \\
10.29\end{array}$ & $\begin{array}{l}13.70 \\
11.15\end{array}$ & $\begin{array}{l}0.53 \\
0.86 \\
\end{array}$ & $\begin{array}{r}13.5 \\
4.0 \\
3.4 \\
\end{array}$ & $\begin{array}{r}1.55 \\
13.55 \\
9.93 \\
\end{array}$ & $\begin{array}{r}13.12 \\
13.81 \\
10.97 \\
\end{array}$ & $\begin{array}{l}0.57 \\
0.26 \\
0.94 \\
\end{array}$ & $\begin{array}{r}7.5 \\
9.9 \\
9.5 \\
\end{array}$ \\
\hline
\end{tabular}




\section{ALTERNATIVE ENERGY COSTS}

The cost of energy to industry and agriculture may vary from supplier to supplier depending upon specific fuel requirements and established contracts. Generally, geothermal energy is competing with natural gas, petroleum products and nuclear fuel. The cost of these fuels can range from below $\$ 1.00$ to $\$ 3.00$ per million BTU's. Competitive costs of fuel presently are about $\$ 2.20$ per million BTU. If geothermal energy can be produced for this cost, it should be considered cost competitive from the government's point of view, although industry might be able to procure cheaper fuel.

An important factor to keep in mind is the current trend of escalation of fuel costs. Table 21 shows the trend of fuel costs for utilities in California and Hawail (from Moody's Public Utilities Manual). Currently commercial gas prices in the PG\&E region range from $21.9 \notin$ per therm to $22.9 \notin$ per therm or $\$ 2.19$ to $\$ 2.29$ per million BTU, in the SCE region $\$ 1.88$ to $\$ 1.98$ per million BTU, and in the San Diego region $\$ 2.35$ to $\$ 2.45$ per million BTU.

Table 22 displays the estimated landed cost of imported crude petroleum from selected countries for the first three months of 1978 .

In March, 1978, the refiner acquisition cost of domestic crude petroleum was $\$ 10.45$ per bbl; imported crude was $\$ 14.57$ per bbl and the composite cost was $\$ 12.23$ per bbl or $\$ 2.23$ per million BTU before refining. The average cost for all grades of No. 6 residual fuel oil was $\$ 12.63$ per barrel or $\$ 2.30$ per million BTU in March 1978. Table 23 displays the costs of coal, residual fuel oil, and natural gas from October 1976 to October 1977. 
Table 21. Fuel Costs for Major Utilities in California and Hawaii 1971-1976

$1971 \quad \underline{1972} \quad \underline{1973} \quad \underline{1974} \quad \underline{1975} \quad \underline{1976}$

Paciflc Gas \& Electric Company

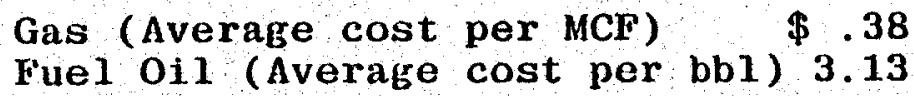

A11 Fuel (Average cost per

militon Btu)

.36

$\$ .41$

4.04

$\$ .47$
5.01

$\$ .68$

$\$ 1.29$

10.88

15.40

$\$ 1.78$

.40

.49

1.03

1.60

Southern California Edison

Gas (Average cost per MCF) .36

Fuel oil (Average cost per bb1) 3.69

All Fuel (Average cost per

million Btu)

.39

.39

.42

5.93

.61
12.08

.85

4.80

.65

1.19

16.33

15.90

.44

1.76

1.80

San Diego Gas \& Electric

Gas (Average cost per MCP) .42

Fuel oil (Average cost per bb1) 4.15

A11 Fuel (Average cost per

milion Btu)

.48

.44

.48

5.00

5.00

.64

9.87

$-$

1.57

.58

Hawailan Electric Company

Fuel oil (Cost per bbl)
All Fuel (Average cost per
million Btu)

3.25

3.32

4. 17

5.28

9.76

10.05

.53

.67

.84

1.56

1.59 
Table 22

Estimated Landed Cost of Imported Crude Petroleum From Selected Countries

( $\$$ per million BTU, assuming 5.49 million BTU per bbl of oil)

$\$$ PER MILLION BTU

\begin{tabular}{lccc} 
& January & February & March \\
\cline { 2 - 4 } Algeria & $\$ 2.73$ & 2.71 & 2.68 \\
Canada & 2.61 & 2.60 & 2.45 \\
Indonesia & 2.65 & 2.65 & 2.65 \\
Iran & 2.53 & 2.50 & 2.56 \\
Libya & 2.66 & 2.70 & 2.66 \\
Nigeria & 2.71 & 2.71 & 2.71 \\
Saudi Arabia & 2.54 & 2.54 & 2.56 \\
U.A. Emirates & 2.62 & 2.56 & 2.63 \\
Venezuela & 2.37 & 2.36 & 2.41
\end{tabular}


Cost Per Mililon BTU For Pacific Region of U.S.

\begin{tabular}{|c|c|c|c|}
\hline & Coal & $\begin{array}{l}\text { Residual } \\
\text { Fuel Oil } \\
\end{array}$ & $\begin{array}{l}\text { Natural } \\
\text { GaS }\end{array}$ \\
\hline October 1976 & $\$ .76$ & $\$ 2.312$ & $\$ 1.690$ \\
\hline November 1976 & .756 & 2.341 & 1.775 \\
\hline December 1976 & .745 & 2.334 & 1.887 \\
\hline January 1977 & .776 & 2.313 & 1.968 \\
\hline February 1977 & .805 & 2.310 & 1.892 \\
\hline March 1977 & .740 & 2.321 & 1.810 \\
\hline April 1977 & .708 & 2.358 & 2.045 \\
\hline May 1977 & .708 & 2.352 & 2.089 \\
\hline June 1977 & .712 & 2.357 & 2.005 \\
\hline July 1977 & .717 & 2.400 & 2.110 \\
\hline August 1977 & .711 & 2.401 & 2.188 \\
\hline September 1977 & .713 & 2.406 & 2.179 \\
\hline October 1977 & .714 & 2.416 & 2.197 \\
\hline
\end{tabular}


Table 24 displays the range of electricity costs for lighting, appliances, refrigeration, cooking and water heating for selected cities in California and Hawail. The ranges are for different usage levels, from $100 \mathrm{kWh}$ and less to 1000 plus $\mathrm{kWh}$, from Typical Electric Bills, 1977 (FPC).

\section{Table 24}

Range of Electricity Costs for Selected Cities in California and Hawail for Lighting, Refrigeration, Cooking, and Water Heating, January 1, 1977

\begin{tabular}{|c|c|c|}
\hline CITY & UTILITY & MILL/KWH \\
\hline Eureka & PG\&E & $30.5-45.5$ \\
\hline Redding & City of Redding Electric Co. & $14 \cdot 6-24 \cdot 7$ \\
\hline San Francisco & PG\&E & $29.4-40.5$ \\
\hline Sacramento & SMUD & $18 \cdot 3-39 \cdot 5$ \\
\hline San Luis Obispo & PG\&E & $30.6-45.5$ \\
\hline Fresno & PG\&E & $30.2-43.5$ \\
\hline Santa Barbara & SCE & $37.2-65.5$ \\
\hline Bakersfield & PG\&E & $30.2-43.5$ \\
\hline Los Angeles & LADWP & $37.2-62 \cdot 6$ \\
\hline Riverside & Riverside Public Utilities & $43 \cdot 3-72 \cdot 2$ \\
\hline San Bernardino & SCE & $37.2-65.5$ \\
\hline San Diego & SDG\&E & $42 \cdot 3-59 \cdot 0$ \\
\hline E1 Centro & IID & $30.9-52.1$ \\
\hline Hilo & HELCO & $63.5-80.2$ \\
\hline Honolulu & HELCO & $45 \cdot 3-80.0$ \\
\hline Kahului & Maui Electric Co. & $58.6-106.0$ \\
\hline Lihue & Citizens Utility Co. & $68.9-107.7$ \\
\hline
\end{tabular}


8. CAPITAL COST OF SUPPLYING COMPETITIVE GEOTHERMAL FUEL

Geothermal resources will be realized at different costs for each specific location. Some locations will have resources that will be cost competitive with alternative fuels, while others will be marginal, requiring tax incentives to make them competitive with natural gas, fuel oil, coal and uranium.

There are other uncertainties as to the exact character of the geothermal resources in California and Hawail. The temperatures, depth, chemical composition, and flow rate of resources throughout both states have yet to be assessed. These factors will all have an impact upon the capital costs of deve1opment and the operating and maintenance costs once production begins. In light of the vast amount of geothermal resources yet to be assessed, a generic approach will be used to make estimates of the capital costs necessary to develop geothermal energy which will provide heat at a cost competitive with variously priced fuels.

The GEYSER model, developed at SAI, was used to make estimates of the capital costs required. The model was originally designed to calculate the price of a product or return on investment, given the capital and operating costs as well as other economic variables. The model was modified to determine the capital cost requirements given that the competitive cost of energy and required return on investment are known. In this way we can determine approximately the cost limitations of getting a certain amount of BTU's into service. The model was also used to determine the impact of the proposed tax incentives upon the capital cost limitations and the return on investment.

The model was used to determine what the capital costs would be to develop energy at different costs per unit of output. In this case, the cost requirements needed to provide a facility 
that would produce $20 \times 10^{9}$ BTU per year were calculated. Table 25 outlines the general economic assumptions used for this analysis.

Table 25

Basic Assumptions For Costing Direct Heat Applications of Geothermal Energy

$\begin{array}{ll}\text { Capital Development Time } & 1 \text { year } \\ \text { Life of the Investment } & 20 \text { years } \\ \text { Price of Energy } & \$ 2.20 \text { per million BTU } \\ \text { Volume of Output per Year } & 20 \times 10^{9} \text { BTU } \\ \text { Operating and Maintenance } & 30 \% \text { of Yearly Revenues } \\ \text { Depreciation } & \text { Double Declining Balance } \\ \text { Debt } & 50 \% \text { of Financing } \\ \text { Interest Rate } & 9 \% \\ \text { Depletion Allowance } & \text { None } \\ \text { Expense of Intangible } & \\ \quad \text { Driliing Cost } & \text { None } \\ \text { Investment Tax Credit } & 10 \% \\ \text { Return on Investment } & 12 \% \\ \text { Escalation Factors } & \text { None (Constant Dollars) }\end{array}$

The results of the analysis are displayed in Figure 12 , which shows a linear relationship between capital costs and price per million BTU's. If the competitive cost of natural gas is $\$ 2.20$ per million BTU, a facility generating $20 \times 10^{9}$ BTU per year will have annual revenues of $\$ 44,000$. In order to achieve a $12 \%$ return on equity ( $50 \%$ of the capital investment is financed by debt at a $9 \%$ interest rate), a total capital investment of $\$ 238,574$ must be made. The entrepeneur's share of the investment would be $\$ 119,287$. An additional $\$ 119,287$ would be provided by debt financing. 


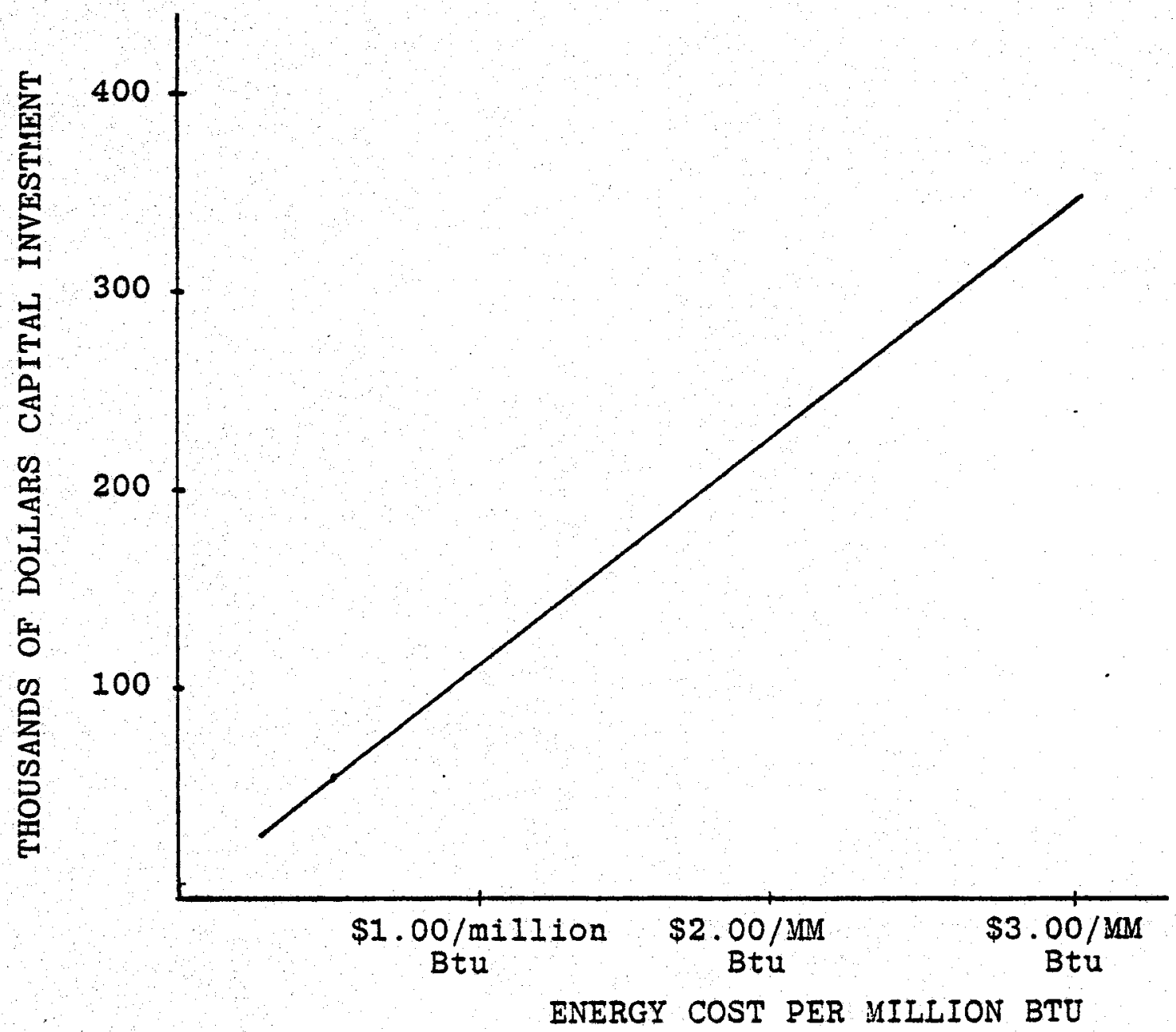

Figure 12. Capital Costs Associated with Competitive Prices of Alternative Energy (Assuming a $12 \%$ Rate of Return, Op. \& Maint. Costs $=30 \%$ of Yearly Revenue, Producing $20 \times 10^{9}$ BTU's ) 


\section{THE IMPACT OF TAX INCENTIVES}

One vehicle the federal government has provided to increase the capital cost limitations for geothermal development is the enactment of tax incentives. The Energy Bill recently passed through Congress provides for three important tax incentives that should have a dramatic impact upon the acceleration of the commercialization of geothermal energy.

The tax incentives include:

1. Percentage Depletion (22\% in 1978 declining by schedule to $15 \%$ by 1984 )

2. Early expension of intangible drilling costs

3. An additional $10 \%$ Investment Tax Credit (totalling 20\%)

The tax incentives are retroactive to January 1, 1978. Development activities this year will be able to benefit.

Tax incentives provide for a reduction in the tax liability of the company. The company must be profitable in order to take advantage of the incentives, otherwise there is no benefit. It is a subsidy from the federal government in terms of revenues it will not collect from the developer.

The tax incentives can have a substantial impact on the return on investment, the price of the product, or the capital cost limitations required for development. Following is a description of each incentive.

9.1 DEPLETION ALLOWANCE

The depletion allowance provides for a percentage of total revenues (less royalties) to be written off as an expense, 
thus reducing net income before taxes. The impact of the depletion allowance is determined by the effective tax rates. It reduces federal taxes and state taxes in California. Depletion is to the resource what depreciation is to the capital investment. The depletion allowance may not exceed $50 \%$ of taxable income.

\subsection{INTANGIBLE DRILLING COSTS}

While drilling is a capital investment it does not provide a tanglble product which has a salvageable value. Allowing the early expensing of intangible drilling costs is effectively a form of accelerated depreciation, allowing for quick recovery of drilling costs. The intangibles may be as high as $70 \%$ of drilling costs and include such items as labor, fuel and power, materials and supplies, tool rental, truck and auto hire, repairs to drilling equipment and depreciation upon drilling equipment.

The investment tax credit is a direct reduction in tax liability. A $20 \%$ investment tax credit allows for $20 \%$ of the capital cost of the investment, to be deducted from the tax liakility. The amount of ITC that can be used in a given year is limited only by the extent of the tax liability. A company may not have to pay any taxes for several years. If a company has a large tax liability from other operations, it may be able to claim the entire ITC in the first year of operation providing a substantial benefit.

There are different frameworks for evaluating the impact of tax incentives. One view might be to assume that an entrepreneur would be willing to accept a $12 \%$ return on investment and that a tax incentive then gives him an extra margin of capital which he might not otherwise risk. Another would be that tax incentives can increase the effective return on investment, 
making geothermal energy more profitable and encouraging further development. Another possibility is that the tax incentive could be used to lower the unit energy cost, in which case the benefit could be passed on to the consumer. If the tax break increases the return on investment, the benefit would be retained by the developer. The government might take the view that given the uncertainty as to capital costs (due to varying drilling depths), an additional margin of capital should be invested while assuring that an acceptable return can still be achieved. If a $12 \%$ return on investment is a criterion for development, then the capital costs limitation for the developer would be $\$ 216,884$ for the example given above. The businessman would not budget more than this amount for development; in fact, he would probably budget much less. If in the course of the development activities he found that it was unlikely that the project could be accomplished for less than this amount, the project might be cancelled. If a 5\% return were sufficient, then he could afford to budget $\$ 337,000$ for the same endeavor. A private entrepreneur would probably not want to accept such a low return; however, government discount rates are much lower than private enterprise and $5 \%$ might be deemed acceptable.

If the entrepreneur cannot accept a lower return, the government can, by utilization of tax incentives, bring about the possible impact of increasing the amount of venture capital the entrepreneur would be willing to invest.

The government is in effect increasing the amount of capital that industry might be willing to venture for geothermal energy. Industry can then develop a larger volume of resources before it reaches the point where it can no longer earn its $12 \%$ on the investment. Table 26 displays capital cost limitations for different acceptable returns on investment under the conditions outlined above to produce $20 \times 10^{9}$ BTU per year. 
Capital Cost Limitation For Rates of Return On Investment To Provide $20 \times 10^{9} \mathrm{BTU} / \mathrm{Yr}$

\section{(Assumptions Table 25)}

\begin{tabular}{cc} 
RETURN ON INVESTMENT & CAPITAL COST LIMITATION \\
\hline $5 \%$ & $\$ 337,224$ \\
$10 \%$ & 238,574 \\
$12 \%$ & 263,378 \\
$20 \%$ & 165,351
\end{tabular}

It can be seen that if a $5 \%$ return is acceptable rather than a $10 \%$ return, the additional $\$ 98,650$ can be allocated towards proving and developing the resource, increasing the capital cost limitation by $41.3 \%$. The impact of tax incentives upon the capital cost limitations is given in Table 27 which follows. For this analysis, it was assumed that the Developer Industry is a large company capable of writing off the tax incentives in the first year of production. The tax liability is not a limiting factor. 
Impact of Tax Incentives Upon Capital Cost Limitations of System To Produce $20 \times 10^{9}$ BTU's Per Year

\section{(Assumptions Table 25)}

\section{TAX INCENTIVES}

Base Case (No Incentives, $10 \%$ ITC)

Depletion Allowance

(22\% till 1984, then 15\%)

Investment Tax Credit (25\%)*

Intangible Drilling cost

( $50 \%$ of Capita1)

Depletion, ITC

Depletion, Intangibles

ITC, Intangibles

Depletion, ITC, and

Intangibles
CAPITAL COST

LIMITATIONS

$\$ 238,574$

314,443

346,411

283,003

456,572

372,998

347,084

457,460
\% INCREASE

OVER BASE COST

*The ITC in the existing energy package is $20 \%$ and will go into effect if the bill is signed.

Tax incentives may impact larger companies more favorably than smaller ones. Large companies have greater tax liabilities, spread over many enterprises, while smaller companies may be limited to the immediate geothermal ventures. A large company may be able to claim the entire Investment Tax Credit in a single year, simply because it has a large enough tax liability to accommodate the whole ITC. The larger company then receives its incentive at a faster rate and, depending upon the discount rate, receives a greater benefit. This means that if the larger company wants to pass the tax savings on to the public, it could sel1 the energy at a lower cost than the smaller company, or if 
it prefers to keep the benefit for further exploration and development, it can have more capital avallable from tax benefit resources. The tables following, 28 and 29 , display the impact of the tax incentives under both conditions. The level of tax liability may be a limitation upon the benefit.

Table 28

Impact of Tax Incentives For A Large Company

Tax Incentive

BASE CASE

Depletion Allowance (22\%, declining to $15 \%$ in 1984)

Investment Tax Credit (25\%) *

Expensing Intangible Drilling Cost (50\% of Capital)

Depletion Allowance, ITC

Depletion Allowance, Intangibles

Intangibles, ITC

Depletion, ITC, Intangibles
Cost of Energy $\$$ per Million BTU (with $12 \%$ return on investment)

*The TTC in the existing energy bill is $20 \%$.

These large differences in prices are assuming that the company is willing to accept a $12 \%$ return on investment and pass the savings on to the market. The large tax incentive in the first year has a dramatic impact when revenues are discounted over time. A dollar benefit in year one is better than a dollar benefit in year two.

In the case of a smaller company that has tax liability limitations, the impact is much more reserved, as displayed in Table 29. 
Impact of Tax Incentives Upon A Smaller

Company With A Tax Liability Limitation

Cost of Energy

$\$$ per Militon

BTU

\section{BASE CASE}

Depletion

Investment Tax Credit (25\%) *

Intangible Drilling Cost

Depletion and ITC

Depletion and Intangibles

ITC and Intangibles

Depletion, ITC, and Intangibles
$\$ 2.20$

2.04

2.20

2.14

2.04

2.02

2.15

2.02
$\%$ of

Reduction

*The ITC in the existing energy bill is $20 \%$.

Surprisingly, the investment tax credit has no impact. This is because the small company is not able to utilize the exisiting $10 \%$ ITC it already has. The tax liability limitation effectively puts off the ITC for over seven years, at which time it can no longer be clalmed. Even if it could be claimed at this time, the tax incentive would only be worth $45 \%$ of its initial value after seven years, and then most likely only a small portion could be claimed each year. 
The market for electric power production in California is adequate to absorb geothermal resources as they are currently projected to come on-line to the year 2000. CERCDC anticipates that an additional 24,000 MWe of installed capacity will be needed by 1995. Utility plans for electric power-on-line include $34,640 \mathrm{MWe}$ by 1995 . The estimated geothermal reserves in California are 20,000 MWe. Siting difficulties with alternatively fueled plants have given incentive to plan for more geothermal plants, which can easily be incremented to the energy mix because the lead times before production are shorter and the power plants are smaller. Demonstration of power generation from liquid-dominated resources should further accelerate development activity. Once geothermal energy is proved viable, utilities should plan for more geothermal. Utilities have already displaced existing plans for alternative fuel plants with geothermal.

Recommendation:

DOE support to facilitate the demonstration of liquid dominated geothermal electric power generation until its viabili$y$ is proven will accelerate development of the resource. support should include flash, binary and hybrid systems.

Tax incentives in the form of depletion allowance, investment tax credits, and intangible drilling costs write-offs have been included in the existing energy bill. These incentives can have a substantial impact upon lowering the cost of geothermal fuel, increasing the return on investment for a geothermal venture, and increasing the amount of capital which entrepreneurs should be willing to invest. The incentives will have the impact of making many marginal resources economically competitive and in some cases, very competitive. The benefits of the tax incentives should be pointed out to potential industrial users, as well as 
the existing developers and utilities.

Recommendation:

Dissemination of tax benefit information to potential beneficiaries with regard to direct heat applications, as well as electric power producers, should have positive effects in accelerating commercial development of the resource.

Six major industries were addressed in the document. of these, four would appear to be of particular interest:

1) Food Processing (a variety of applications)

2) Lumber \& Wood Processing

3) Paper Processing

4) Chemical Processing (a variety of applications)

These four industries account for $35 \%$ of the purchased fuels and electric energy used for heat and power for industries in California. California leads the nation in the production of over fifty crops and accounts for over $50 \%$ of the U.S. production of thirty-six crops. Agriculture and food processing are very important industries in California. Virtually every county in Northern California produces lumber, wood, and paper. The paper and paperboard industry is the fourth largest industry in the country, with the fifth fastest rate of real growth. The chemical industry is the most energy intensive industry, energy accounting for the highest percentage of product cost of any industrial classification. These major industries are prime targets for the use of geothermal process heat and warrant special consideration.

\section{Recommendation:}

A DOE-sponsored market analysis of the lumber, wood, and paper industry in Northern California should have positive effects on accelerating resource development. 
Recommendation:

A DOE-sponsored study of the chemical industry in California and Hawail should have positive effects on resource development.

\section{Recommendation:}

A DOE-sponsored study of the food processing industry in California and Hawail should have positive effects on resource development.

\section{Recommendation:}

A DOE-sponsored demonstration of direct use applications of geothermal energy in California and Hawaii, with particular emphasis on industrial uses such as the food processing, lumber and paper, and chemical industries should accelerate commercial utilization of the resource.

California contains many industries and many markets. There are fifty-eight counties in California and over 36,000 manufacturing establishments, including over 2,300 food processing establishments, 1,000 lumber establishments, 30 pulp and paper mills, and 1,200 chemical companies. Many of these companies have probably not considered geothermal energy as an alternative. It would be valuable to determine the industrial attitude toward geothermal energy and increase industry's awareness of this energy alternative.

\section{Recommendation:}

Sample industrial process heat users to assess attitudes towards geothermal energy and related issues, by authorized marketing research instrument (questionnaire, interview). 
The major markets for industrial process heat applications in California center around the San Francisco Bay area and Los Angeles, and other coastal cities. In Hawail, the Island of Oahu provides the major market. In the case of both California and Hawail, the proven resources capable of industrial use do not coincide with the urban market locations. Still, there is a great amount of unexplored territory which may hold considerable promise. The Direct Use Overview points to hot springs and geologic characteristics that indicate potential resources which are in the vicinity of the strong urban markets.

Recommendation:

DOE-sponsored exploration and assessment of resources which are located in proximity to major existing markets such as Contra Costa and Los Angeles County in California and the Island of Oahu in Hawail should have positive effects on accelerating commercialization of the resource. 


\section{BIBLIOGRAPHY}

1. CERCDC, Energy Watch, Aug. 1978.

2. Ahern,... et al., Energy Alternatives for California: Paths to the Future, RAND Corp, Santa Monica.

3. State of California, California Statistical Abstract, 1977 .

4. Fredrickson, C. Collected Information From the California Public Utilities Commission, JPL 1978.

5. CERCDC, California Energy Trends and Choices, Vol. 2, Electricity Forecasting and Planning, 1977 .

6. CPUC, Forms $R-3 A, R-4 A, R-4 B, R-5$, for California Utilities, 1977 .

7. Trehan, et a1., Site Specific Analysis of Geothermal Development - Scenarios and Requirements, MITRE Corp.

8. U.S. Department of Commerce, Industry and Trade Administration, U.S. Industrial Outlook, 1978 .

9. U.S. Department of Commerce, Bureau of Census, Annual Survey of Manufacturers Fuels and Electric Energy Consumed 1976 .

10. U.S. Department of Commerce, Bureau of Census, County Business Patterns, 1976.

11. Commerce Clearing House, Inc. $1978 \mathrm{U} . \mathrm{S}$. Master Tax Guide.

12. CERCDC, Quarterly Fuel and Energy Summaries.

13. Hawaii Electric Light Co,, R, G, H, and $P$ Rate Schedules, 1978 .

14. Action Resources Incorporated - Progress Reports to SAI, 1978.

15. Pacific Analysis Corporation - Progress Reports to SAI, 1978.

16. Science Applications, Inc., La Jolla, CA, 1978, "Direct Use Overview for California", Preliminary Draft.

17. Larson, T., "Economic Feasibility Model for Direct Heat Applications of Geothermal Energy," Geothermal Resources Council Transactions, 1978 . 
18. Jacobson and Williams, Postulated Geothermal Non-Electric Development Site Specific Scenarios, Vol. II, MITRE Corp.

19. U.S. Department of Energy, Energy Information Administration, Division of Consumption Data Studies, Federal Energy Data System (FEDS), statistical summary Feb. 1978 .

20. U.S. Department of Commerce, OBERS PROJECTIONS, Series A and Series $C$.

21. Federal Power Commission, Typical Electric Bills, 1977.

22. U.S. Department of Energy, Energy Information Administration Annual Report to Congress, Vol. II, 1977: Projections of Energy Supply and Demand and their Impacts.

23. U.S. Department of Commerce, Social and Economic Statistics Administration, Bureau of Economic Analysis, Area Economic Proejctions 1990, 1976.

24. U.S. Department of Commerce, Bureau of the Census. Statistical Abstract of the United States, 1977. 
PURCHASED FUELS AND ELECTRIC ENERGY CONSUMED IN CALIFORNIA OOUNTIES FOR SIX MAJOR PROCESS HEAT USING INDUSTRIES (BILLION BTUS)

Food Lumber Paper Chemical Oil Rubber

\begin{tabular}{|c|c|c|c|c|c|c|}
\hline Alameda & $8,068.5$ & 336.8 & $3,394.6$ & $6,150.7$ & $1,535.4$ & 371.7 \\
\hline Alpine & - & - & - & - & - & - \\
\hline Amadore & - & 271.2 & - & - & - & - \\
\hline Butte & 438.7 & 495.4 & - & - & - & 12.7 . \\
\hline Calaveras & - & 18.1 & - & - & - & - \\
\hline Colusa & 39.4 & - & - & - & - & - \\
\hline Contra Costa & $1,534.4$ & 70.4 & $2,280.3$ & $3,937.3$ & $39,725.3$ & 48.8 \\
\hline Del Norte & 33.4 & 554.9 & - & - & - & - \\
\hline El Dorado & - & 207.6 & - & - & - & 37.2 \\
\hline Fresno & $3,802.5$ & 374.5 & 166.7 & $1,034.8$ & - & 74.3 \\
\hline Glenn & 282.4 & 63.5 & - & - & - & - \\
\hline Humboldt & 327.2 & $2,310.2$ & 395.7 & - & - & - \\
\hline Imperial & 362.6 & - & - & 204.4 & - & - \\
\hline Inyo & 33.4 & - & - & - & - & - \\
\hline Kern & 779.2 & 75.5 & - & 325.9 & $7,332.5$ & 88.6 \\
\hline Kings & 459.4 & - & - & 113.3 & $3,079.2$ & 159.3 \\
\hline Lake & - & 25.8 & - & - & - & - \\
\hline Lassen & - & 151.0 & - & - & - & - \\
\hline Los Angeles & $31,644.3$ & $3,882.7$ & $16,514.9$ & $30,226.7$ & $73,743.9$ & $6,753.9$ \\
\hline Madera & 758.5 & 152.8 & - & - & - & 10.6 \\
\hline Marin & 85.5 & - & - & - & - & 78.4 \\
\hline Mariposa & & - & - & - & - & - \\
\hline Mendocino & 93.5 & $1,116.3$ & - & - & - & - \\
\hline Merced & $2,437.1$ & 110.3 & 52.8 & - & - & 13.2 \\
\hline Modoc & - & 53.3 & - & - & - & \\
\hline
\end{tabular}




\begin{tabular}{|c|c|c|c|c|c|c|}
\hline Sono & - & - & - & - & - & - \\
\hline Monterey & $2,228.8$ & 34.5 & 184.7 & 58.4 & - & 371.7 \\
\hline Napa & 618.9 & 63.5 & - & 204.4 & - & - \\
\hline Orange & $4,202.5$ & 855.7 & $4,397.0$ & $6,367.9$ & $1,650.4$ & $1,663.1$ \\
\hline Placer & - & 280.5 & - & - & - & 69.0 \\
\hline Plumas & - & 299.0 & - & - & - & - \\
\hline Riverside & 885.4 & 691.0 & 791.4 & 735.8 & - & 104.5 \\
\hline Sacramento & $2,434.4$ & 510.2 & 453.7 & 661.1 & - & 29.1 \\
\hline San Benito & 116.8 & - & 52.8 & 438.0 & - & - \\
\hline San Bernardinc & o $1,583.1$ & 373.8 & 382.0 & $1,287,1$ & - & 242.6 \\
\hline San Diego & $2,973.3$ & $268.9 q$ & 317.6 & $2,047.5$ & 656.9 & 199.0 \\
\hline San Francisco & $3,159.5$ & 136.5 & 494.9 & 899.4 & - & 114.1 \\
\hline San Joaquin & $4,350.1$ & 647.4 & 791.4 & 869.0 & - & 99.4 \\
\hline San Luis & & & & & & \\
\hline Obispo & 101.5 & 18.1 & - & - & 410.5 & - \\
\hline San Mateo & $2,085.9$ & 103.4 & 919.1 & $1,747.3$ & 615.8 & 631.3 \\
\hline Santa Barbara & $1,069.0$ & 39.9 & - & - & 410.5 & 37.2 \\
\hline Santa Clara & $6,438.6$ & 250.8 & $1,846.6$ & $2,657.2$ & 410.5 & 429.6 \\
\hline Santa Cruz & $2,185.4$ & 161.1 & - & - & - & 35.7 \\
\hline Shasta & 112.8 & 974.7 & 791.4 & - & - & 10.6 \\
\hline Sierra & - & 18.1 & - & - & - & - \\
\hline Siskiyou & 46.1 & 643.8 & - & - & - & - \\
\hline Solano & 942.8 & 54.8 & 55.9 & - & $3,079.2$ & - \\
\hline Sonoma & $1,408.8$ & 516.8 & - & - & - & 37.2 \\
\hline Stanislaus & $6,422.6$ & 179.3 & $1,086.8$ & 204.4 & - & 22.5 \\
\hline Sutter & 425.3 & 117.6 & - & - & - & - \\
\hline Tehama & 155.6 & 404.3 & 395.7 & - & - & - \\
\hline Trinity & - & 136.1 & & & - & - \\
\hline Tulare & $1,149.1$ & 433.7 & 184.7 & - & - & 42.3 \\
\hline Tuolume & - & 241.7 & - & - & - & - \\
\hline
\end{tabular}


Ventura

Yolo

Yuba

$\begin{array}{rr}1,197.8 & 136.5 \\ 929.4 & 321.2 \\ 41.4 & 221.4\end{array}$

$41.4 \quad 221.4$
797.7

395.7
210.2

114.5
886.8

237.9

22.1 